University of Rhode Island

DigitalCommons@URI

Open Access Master's Theses

1997

\title{
SUITABILITY ANALYSIS FOR DETERMINING NEW RESIDENTIAL DEVELOPMENTS IN GAZA STRIP, PALESTINE
}

Richard J. Jabba

University of Rhode Island

Follow this and additional works at: https://digitalcommons.uri.edu/theses

\section{Recommended Citation}

Jabba, Richard J., "SUITABILITY ANALYSIS FOR DETERMINING NEW RESIDENTIAL DEVELOPMENTS IN GAZA STRIP, PALESTINE" (1997). Open Access Master's Theses. Paper 583.

https://digitalcommons.uri.edu/theses/583

This Thesis is brought to you for free and open access by DigitalCommons@URI. It has been accepted for inclusion in Open Access Master's Theses by an authorized administrator of DigitalCommons@URI. For more information, please contact digitalcommons-group@uri.edu. 
SUITABILITY ANALYSIS FOR DETERMINING NEW RESIDENTIAL DEVELOPMENTS IN GAZA STRIP, PALESTINE

BY

RICHARD J. JABBA

A RESEARCH PROJECT SUBMITTED IN PARTIAL FULFILLMENT OF THE REQUIREMENTS FOR THE DEGREE OF MASTER OF COMMUNITY PLANNING

UNIVERSITY OF RHODE ISLAND 1997 
SUITABILITY ANALYSIS FOR DETERMINING NEW RESIDENTIAL DEVELOPMENTS IN GAZA STRIP, PALESTINE

BY

RICHARD J. JABBA
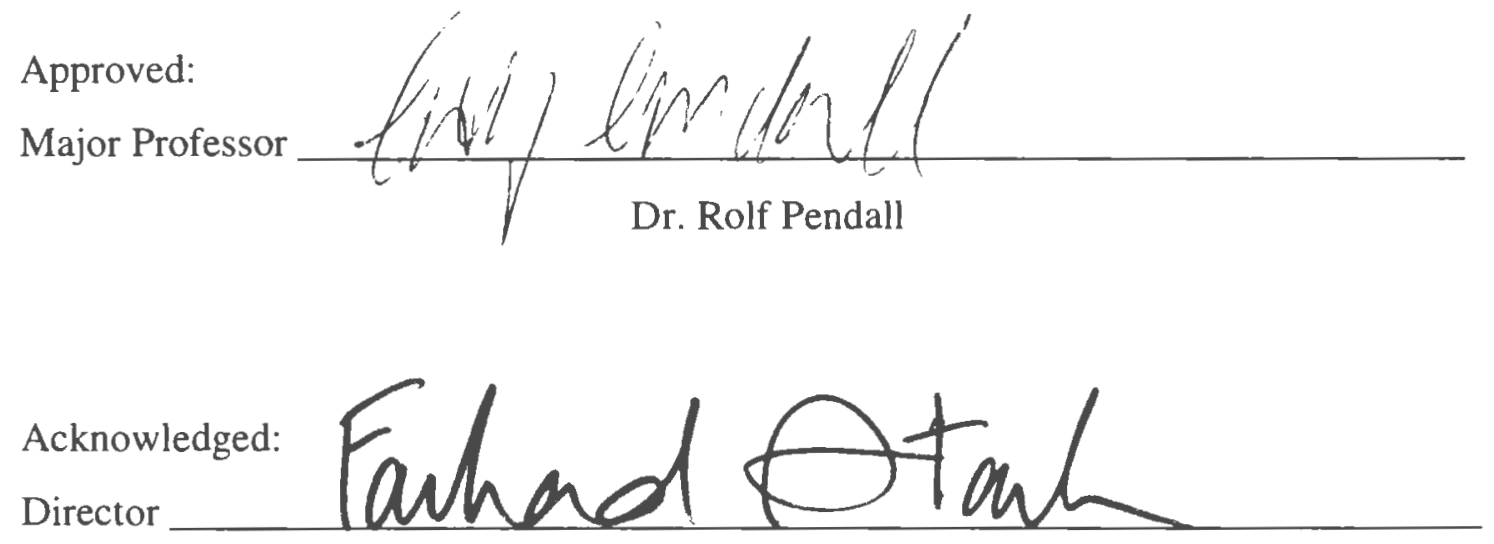

Dr. Farhad Atash 


\section{ACKNOWLEDGMENTS}

This study is a result of my internship at the Ministry of Planning and International Cooperation under the Palestinian Authority in Gaza Strip. I am especially thankful for the most rewarding personal and professional experience while working with the Palestinians at the Ministry for two months in the summer of 1996 . Their willingness to learn new planning methods and help me understand the extreme issues within Gaza Strip and the West Bank provided me with many thoughts for this project.

I would like those that I had direct contact while living in Gaza, including the all the Palestinian planners, the Norwegian advisor Oysten Gronning, with whom I worked many hours, and my brother Rafael, who exposed me to life in Gaza.

I would like to thank Dr. Rolf Pendall for his encouragement and continued patience with my drafts, Dr. Atash for his support, Pam Rubinoff for insight of my work, and friends and family that supported me through the whole process. 
TABLE OF CONTENTS

$\begin{array}{ll}\text { RESEARCH ISSUE } & \mathbf{1} \\ \text { BACKGROUND } & \mathbf{2} \\ \text { OBJECTIVES AND SIGNIFICANCE OF THE PROJECT } & \mathbf{3} \\ \text { OBJECTIVE 1 } & 3 \\ \text { OBJECTIVE 2 } & 4 \\ \text { CHAPTER OUTLINE } & 4\end{array}$

CHAPTER II. BACKGROUND AND PRESENT CONDITIONS 6

HISTORICAL OVERVIEW

AN OVERVIEW OF PRESENT CONDITIONS IN GAZA STRIP 8

THE PHYSICAL SETTING 9

1. TOPOGRAPHY 9

2. CLIMATE 11

3. WATER 12

4. Agricultural LAND USE

5. COASTLINE 14

6. BUILT UP AREAS

DEMOGRAPHICS $\quad 15$

POPULATION SIZE

AGE STRUCTURE AND GENDER COMPOSITION 16

$\begin{array}{ll}\text { POPULATION PROJECTIONS } & 17\end{array}$

PLANNING PROCESS AND CHARACTERISTICS 19

LAND OWNERSHIP AND LAND USE PLANNING 19

CURRENT PLANNING AND DEVELOPMENT IN GAZA 23

UNRWA'S ROLE IN PLANNING

CONSTRAINTS TO PLANNING

SUITABILITY ANALYSIS FOR NEW HOUSING 28

METHODS $\quad 28$

MODELS $\quad 29$

$\begin{array}{ll}\text { SUITABILITY ANALYSIS } & 30\end{array}$

\begin{tabular}{lr} 
CHAPTER III. METHODOLOGY & 33 \\
\hline
\end{tabular}

OVERVIEW OF METHODOLOGY - LAND USE ANALYSIS AND ASSESSMENT 33

PROJECT METHOD

LIMITATIONS OF SUITABILITY ANALYSIS METHODS

DETERMINATION OF LAND USE ATTRIBUTES

METHOD

CONDITIONS FOR METHODOLOGY AND ASSESSMENT

HOUSING NEEDS $\quad 43$ 
INTRODUCTION

SUITABILITY LEVELS

PHASING

FINDINGS

TOTAL NEED AND DENSITY LEVELS FOR NEW DEVELOPMENT

LAND NEEDS AND MOST SUITABLE LOCATIONS

CHAPTER V. IMPLEMENTATION AND CONSTRAINTS

IMPLEMENTATION $\quad 53$

COMPACT GROWTH

CONTIGUOUS DEVELOPMENT

PARCELLATION

COMPREHENSIVE PLAN

CONSTRAINTS

POLITICAL ISSUES $\quad 60$

AGRICULTURAL ISSUES $\quad 62$

SOCIAL ISSUES $\quad 63$

CHAPTER VI. CONCLUSIONS $\quad 65$

RESULTS OF MOST SUITABLE LOCATIONS

\begin{tabular}{ll} 
LOCATIONS & 65 \\
\hline
\end{tabular}

$\begin{array}{ll}\text { IMPLEMENTATION } & 66\end{array}$

LIMITATIONS OF THE STUDY

DATA COLLECTION AND LIMITATIONS $\quad 68$

COMMENTS ON METHODOLOGY AND ANALYSIS $\quad 69$

COMMENTS ON IMPLEMENTATION $\quad 70$

AREAS FOR FUTURE STUDY

APPENDIX 1. INTERIM AGREEMENT 


\section{CHAPTER I. INTRODUCTION}

As I walked around a Middle Eastern city, I saw the challenges of modern day planning practices. Past planning efforts have shaped, molded, and contoured the city according to the cultures and practices of past efforts. In the Gaza Strip, I observed a record of "politically driven" planning efforts or at least a society that has not employed a democratic, equitable planning process. When I noticed that some of the highest density areas in the world abut plots that grow flowers, streets that change from 100 feet in width to ten feet surrounded by buildings, and small enclaves of American style single-family ranch homes protected by barbed-wire fence and military personnel, I got strong feelings of consternation. Questions like "What planning efforts allowed this pattern and organization to occur?" and "How can the situation be improved?" rang through my mind. My goal of this project was to help the situation and provide a better method of utilizing land for residential use in Gaza Strip.

\section{RESEARCH ISSUE}

The Palestinian Authority's Ministry of Planning and International Cooperation (MOPIC) is seeking alternative areas for new residential locations Gaza Strip due to present and future demand. MOPIC estimated that 26,000 new housing units are needed between 1995 and 2000 (MOPIC 1995b). MOPIC also expects an estimated 100,000 Palestinians people to return from other countries upon favorable economic and political conditions. 


\section{BACKGROUND}

Gaza Strip has gone through many changeover the past several thousand years. The Romans took rule from the Egyptians in the beginning of the first century. The Ottomans ruled for several hundred years until the early nineteen hundreds. Under the British Mandate in 1920, Gaza was separated from Palestine.

In 1948, the Israelis claimed neighboring areas, including the West Bank and Gaza Strip, as the State of Israel. Palestinians fled their homes from the new state into the West Bank, Gaza Strip, other Middle Eastern countries, and abroad. The population doubled in Gaza Strip almost overnight with refugees (Roy 1995). They were accommodated in camps with help from the United Nations (Euroconsult/Iwaco 1994). From then on, Israel controlled Gaza Strip, and occupied the area from 1967 to 1994, except for a brief period of occupation by Egypt.

Recently, Israel returned civil rule to the Palestinians on the Gaza Strip as a result of the peace process between the two governments. Oslo II and the Gaza-Jericho Agreements placed many conditions on activities within the Strip and increased aid from donor countries to upgrade the infrastructure, and improve the social institutions and economic situation (Brynen 1996).

Present conditions are deplorable: extremely high population density, poor housing conditions; high unemployment, and extremely high population growth rates (Heiberg 
and Ovensen 1993). Israel intermittently places severe restrictions on imports and exports at the border (Roy 1995). For these reasons, MOPIC is currently developing strategies to address housing demand and supply.

\section{OBJECTIVES AND SIGNIFICANCE OF THE PROJECT}

There are two objectives for this study:

1. Determine and analyze new residential locations, and

2. Design an implementation plan and discuss the constraints to development.

Determining areas for new residential development is performed mainly by developers and governmental planning agencies. Researchers have proposed different methods to determine the most suitable areas for residential development. In this study, I devised a model based on several types of suitability models. This model reflects local knowledge of current conditions and needs of residents.

This suitability analysis is one of several components that MOPIC and other agencies could use to determine where they should locate new residential developments. It would be part of a larger regional plan which would include commercial and industrial areas, and community infrastructure.

\section{Objective 1}

This study utilizes a Excel spreadsheet to analyze housing related attributes. A grid is laid over a map and each of the cells are coded based on the attributes scores. Factors, 
such as proximity to transportation, and environmental values are scored for each cell.

The cumulative score is coded and the resulting composite scores are mapped. Levels of suitability are then assigned and the most suitable locations for residential developments are determined.

An analysis of Gaza Strip will result in several residential development suitability levels. The index numbers will identify the most and least suitable areas. Depending on their location, some areas may have to be phased in as performed with in through appropriate management strategies. Of course, the first areas to be developed will depend on other factors such as the availability of land and current economic situation of the Gaza Strip.

\section{Objective 2}

An implementation plan is provides goals and planning methods for the planning agencies to actually create new locations. After this, constraints to implementing goals are addressed. Constraints related to agriculture, economy, politics, refugees, foreign aid, and the implementation process are discussed.

\section{CHAPTER OUTLINE}

I. Introduction and overview of project: issue of need for housing in Gaza; background of historical and present conditions, objectives of study, and chapter outline.

II. Background: review of literature about history of the area, environment and built areas, demographics, population, past and present planning efforts, and suitability analysis. 
III. Methodology: define method to determine the most suitable areas for new residential developments. Based on specific attributes related to housing and planning needs.

IV. Analysis of housing locations: determine the most suitable areas based on development attributes.

V. Implementation and constraints: determine constraints to implementing housing developments.

VI. Conclusions: results, limitations, areas of further study. 


\section{Chapter II. BACKground AND PRESEnt Conditions}

Gaza Strip is an area with a unique background whose human history began several thousand years ago. From a historical perspective, the ideas and activities that shaped, molded, and built Gaza to its present day cultures and structures are complex and, at times, misunderstood. A discussion of Gaza's past and present should help the reader to understand its present political, social, and environmental conditions.

This chapter begins with a discussion about the past and present conditions that led to the need for housing in Gaza. It then reviews the uses and validity of a specific method of analysis to determine the location of new housing developments.

\section{HISTORICAL OVERVIEW}

Housing demand in most Muslim countries stems from economic factors that attract rural residents to major cities (Amirahmadi and El-Shakhs 1993). This is not true, however, of Gaza. The demand for new housing in Gaza is from a unique set of political, geographic, and social sources. Historically, Gaza Strip was part of a larger area controlled by different rulers that established many laws of the land (Goadby and Doukhan 1982). The Romans took rule from the Egyptians of the area in the beginning of the first century (Huxley et. al. 1972). The Ottomans ruled for hundreds of years until the early 1900s. The British Mandate separated Gaza from Palestine until a war in 1948, when Israelis claimed neighboring areas, including the West Bank and Gaza Strip, as the State of Israel. Since 1948, Israel controlled Gaza Strip and its borders except for a ten-year period when 
Egypt assumed control over the Strip's civil administration between 1957 and 1967 (Roy 1995). The Israeli Defence Force physically occupied the area from 1967 to 1994 , and implemented security measures with military orders during that time.

When Israel claimed Gaza Strip in 1948, many Palestinians fled their homes from the new state of Israel into the West Bank, Gaza Strip, other Middle Eastern countries, and abroad. The population doubled in Gaza Strip almost overnight in 1948 (Roy 1995). The refugees were accommodated in permanent refugee camps with help from the United Nations Relief and Works Organization for Palestinian Refugees in the Near East (UNRWA) (Euroconsult/ Iwaco 1994).

UNRWA set up systems for drinking water supply, solid waste management, and improvement of sewers and drainage roads. During occupation, however, the military government restricted land and water use, and did not allow the formation of new institutions to deal with environmental problems or concerns related to developments of this magnitude (Euroconsult/ Iwaco 1994).

Tension and fighting have occurred between Israelis and Palestinians since 1948. Most disputes centered on control of land and religious sites. Recently, Israel returned civil rule of Gaza Strip to the Palestinians as a result of the peace process between the two governments in the early 1990s. The peace process, known as Oslo II and the GazaJericho Agreements, also placed many conditions on activities within the Strip, such as 
restrictions on use of land near the border, and Israel's rights to maintain settlements in the Strip (MFA 1994). It increased aid from donor countries to upgrade infrastructure, and improve social institutions and the economic situation (Brynen 1996a).

\section{AN OVERVIEW OF PRESENT CONDITIONS IN GAZA STRIP}

The current condition of Gaza Strip is extreme by most standards. Neglect of sanitary maintenance and the lack of a functional infrastructure has led to deplorable conditions over the past thirty years. Gaza Strip is one of the places in the world where the exploitation of resources exceeds the carrying capacity of the environment. This is exemplified by the condition of water and land resources, which are under high pressure and prone to severe over-exploitation; groundwater pollution; and soil degradation (Euroconsult/ Iwaco 1994). Many wells are contaminated from inoperative sewers and agricultural runoff, solid waste is dumped illegally throughout the cities, and many agricultural areas are constantly being developed for non-agricultural purposes without long-term planning for needs of the residents of the Strip.

There are numerous social problems in the Strip, as well: high population densities, high unemployment, and poor housing conditions. Furthermore, Israel controls the borders and intermittently places severe restrictions on imports, exports, and the number of Palestinians that are allowed to cross the border to work daily in Israel (Roy 1995).

Given these social and environmental conditions, the Ministry of Planning and International Cooperation (MOPIC) developed strategies for addressing housing needs in 
the Strip (MOPIC 1995b). It is important to understand these conditions as the foundation for planning in the Strip, as discussed in the following paragraphs.

\section{THE PHYSICAL SETTING}

It is important to characterize the landscape and uses of an area to determine the future use of the land. All the land in the Gaza Strip is in use, whether by agriculture, recreation, industries, housing, transportation, or other uses (MOPIC 1996b). Understanding the geography, climate, water, agriculture, and shoreline is critical prior to initiating a planning strategy.

\section{Topography}

The Gaza Strip is located in the western side of Israel and borders the Egypt to the south and the Mediterranean Sea to the west. It is a rectangular shape of $365 \mathrm{~km}^{2},(140$ square miles, 365,000 dunams), about $40 \mathrm{~km}$ ( 28 miles) long, $7 \mathrm{~km}$ (4.3 miles) wide at its northern end, and $12 \mathrm{~km}$ (7.8 miles) wide at its southern end (see FIGURE 1). The borders have remained the same since its creation in 1948. The Strip lies on a flat to rolling, sand- and dune-covered coastal plain, bordered by the Negev desert to the east and the Sinai to the south (Orni and Efrat 1971). The highest point is 132 feet above sea level and is located in Gaza City. The Strip has three narrow, distinct bands of land that run parallel to the shoreline: a wide belt of loose sand that runs from the shoreline to a dune ridge; a central depression with highly fertile alluvial soils; and a sandstone ridge in the east extending into the Negev (Orni and Efrat 1980). The northern third of the Strip isunderlain by Philistian Plain sands, and the southern two-thirds are part of the more 
FIGURE 1. GAZA STRIP

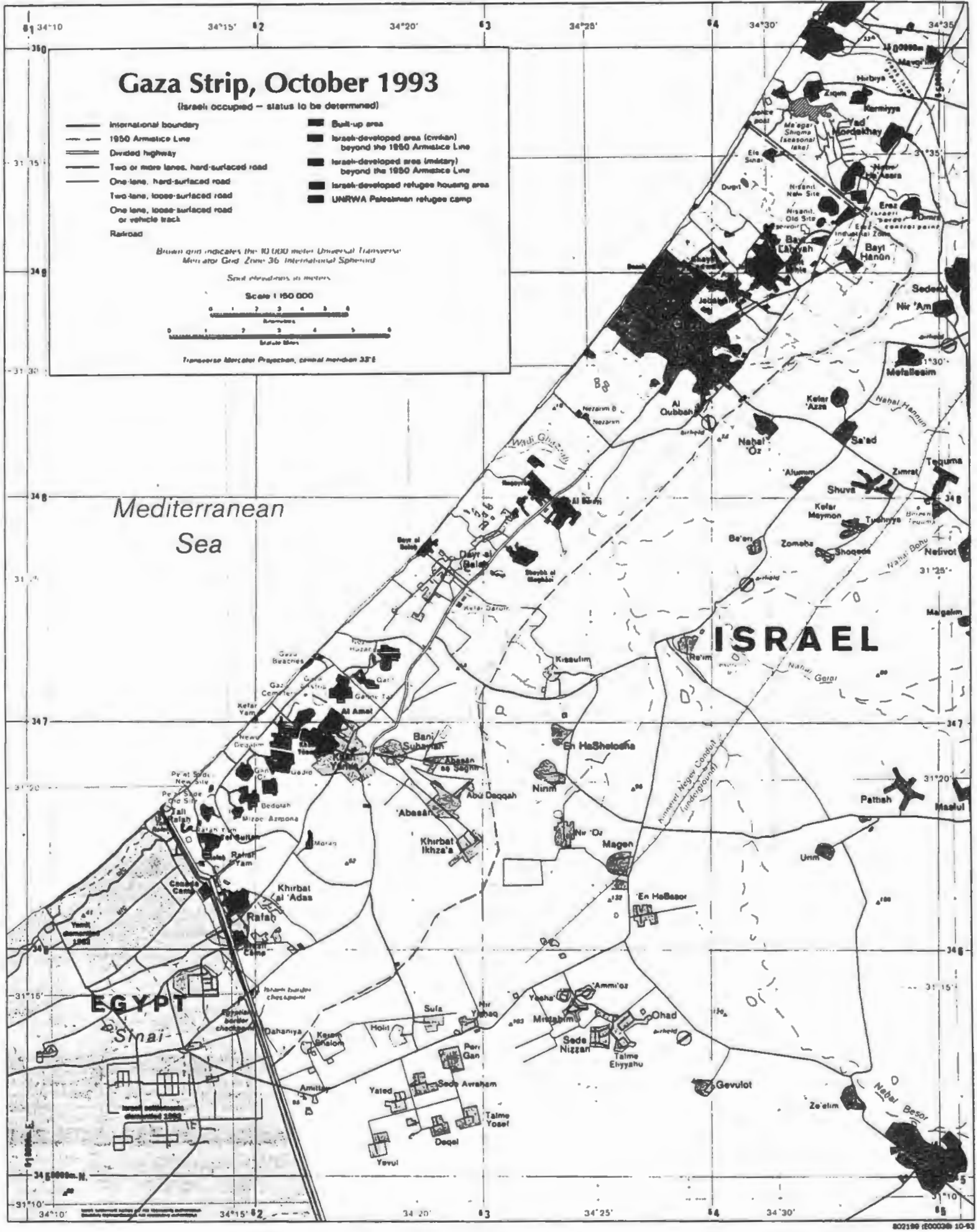


fertile sand loess of the northern Negev coast. A river, Wadi Gaza, separates these two areas. It only runs about 30 days per year because of an intermittent rainfall, and because dams on the Israeli side prevent the flow of water during the rainy season (Roy 1995).

\section{Climate}

The climate is similar to that of southern California with rain between October and April, and cloudless skies between June and October. Average rainfall on the Strip is approximately 400 millimeters per year in the northern sections, and declines to 200 millimeters per year in the southern section. This rain fall contributes about 50 million cubic-meters $(\mathrm{mcm})$ of water per year to the groundwater. Irrigation return flow and waste water recharges to the groundwater adds an additional $20 \mathrm{mcm}$ per year. However, consumption is about $110 \mathrm{mcm}$ per year. This leaves a deficit of about $40 \mathrm{mcm}$ per year (Euroconsult/ Iwaco 1994).

Temperature ranges along the coastal plain are generally $24-27^{\circ} \mathrm{C}$ during the summer and $13-18^{\circ} \mathrm{C}$ during the winter. Most of the buildings are not heated although winter temperatures drop to around $5^{\circ} \mathrm{C}$. Strong ocean breezes prevail during the summer months which cool the interior parts. Fortunately, the city was not built up along its shoreline, unlike the coastal city of Tel Aviv, Israel, such that it prevents cooling ocean breezes from reaching several kilometers inland. MOPIC's recognition of this poor building pattern should be recognized in any decision for coastal development. 


\section{Water}

Water resources are scarce in the Strip. The Gaza Strip contains shallow aquifers about 30 to 40 meters deep (Roy 1995). There are no surface waters except the Wadi Gaza which flows about one month per year. Of the approximate 2000 artisan wells and bore holes, the majority are used for agricultural purposes. Outside the municipalities, residents obtain water from private wells, and inside through a main distribution system. Agricultural uses consume the largest percentage of water (over 70 percent of the total amount) (Euroconsult/ Iwaco 1995:2).

There are two serious problems with groundwater in the Strip: supply and quality. The demand for water has exceeded the replenishment and existing capacity, resulting in a shortage of fresh water. This shortage has resulted in salt water intrusion and increased chloride levels for the past fifteen years. High chloride levels pose public health concern "that is likely to increase kidney disease and dysentery, with children being the primary victims" (Roy 1995:170). The volume of fresh and unpolluted water is decreasing three to four percent per year and will deplete within 30 years unless the government implements corrective measures (MOPIC 1995a). The dune areas in the northern and southwestern areas of the Strip provide relatively good supply of groundwater. These areas are protected under the Emergency Resources Protection Plan (MOPIC 1995b). However, these areas are vulnerable to pollution from agriculture and urban runoff since there are no thick clay layers in the sandy soils to prevent flow from the surface into the 
groundwater. Water is also withdrawn from the Israeli settlement areas for use in Israel and the Strip's settlements. This practice only exacerbates the supply situation.

About 10 percent of the population is not served by any sewer system. Many of the present systems continually overflow on to roadways and into homes. I had to jump over many small runs of sewage while walking around Gaza, especially around the camps and the land between them and the shoreline. The lack of adequate sewer systems contributes to high nitrate levels in groundwater throughout the Strip. High nitrate levels pose health risks, and reduce citrus quality and output (Roy 1995).

Domestic use including non-agricultural business, accounts for about 20 percent of the Strip's water supply. The world standard for domestic water consumption is 250 liters/person/day (lpd). For comparison purposes, the US and Europe consume $400 \mathrm{lpd}$ (106 gallons), Israel 500 lpd (132 gallons), and Gaza 100 lpd (26 gallons) (Roy 1995). The supply and quality of water affects the daily lives of everyone in Gaza.

\section{Agricultural Land Use}

Agricultural lands in the Strip are used mainly for citrus (intensive cultivation) and vegetables and flowers (extensive cultivation). Intensive cultivation yields higher economic returns, and has resulted in a shift of cropping pattern from the clayey areas in the east and central Strip to the sandy areas in the west. Although the intensive areas currently occupy less than one-third of the farmed areas, they generate more than twothirds of the gross agricultural production value (MOPIC 1995b). Much of the land on 
the mid-eastern and southeastern part of the Strip is for rain-fed crops only, and during the dry season the ground remains fallow. Agricultural production is limited to the amount of clean potable water. A poor rainy season or large increase in domestic use would hurt the economy.

\section{Coastline}

The 28 mile coastline of Gaza is one of its most valuable resources. It is the primary recreational area for people living in the Strip. In fact, one study estimated that about one and one half percent of the population $(13,800)$ used the beach between 1:00 and 2:00 PM on a Friday afternoon, and that over three percent of the population $(27,000)$ used the beach on that day (Euroconsult/ Iwaco 1994). A sandy beach with cliff dunes extends the entire length of the Strip's western shore. The coastline is interrupted by several cities, and is dotted with many small buildings. Several fishing fleets utilize the beaches along the coast. There are plans for a new port, a power plant, and hotels that will be supported by foreign investments. The coastline is laden with sewage outfalls. Direct discharge from pipes at the surf zone and beach cliffs poses public health risks for users of the beaches. Even the odor emanating from these sources reaches over 100 meters into nearby camps and town quarters. Recreation, tourism, public health, businesses, and infrastructure activities place severe pressure on this coastline.

\section{Built Up Areas}

There are three main urban areas in the Strip: Gaza City, Khan Yunis, and Rafah (see FIGURE 1). Gaza City has the largest population $(350,000)$, including refugees, of the 
three areas and covers 12.5 square miles. It is also the main administrative and commercial center of the Strip.

Much of the built up area has inferior infrastructural services of roads, water, sewer, electricity, and telephone. They are very old and used over capacity. One main road down the center of the strip connects these towns. It also provides access to Egypt at Rafah and to Israel at Erez. A small, secondary coastal road runs the entire length of the Strip and is broken up several times by the Deir Balah and Shati refugee camps. Most other secondary roads are sand and dirt that turn to mud when it rains. On these and several other roads are many military and check points. The width of some roads through the camps is only 10 feet. An old rail corridor extends between the Rafah and Erez border crossings. While the track no longer exists, most of the right of way is still intact, except where buildings have been constructed without permits (MOPIC 1996).

\section{DEMOGRAPHICS}

\section{Population Size}

The population of Gaza Strip has a substantial impact on the resources. Current population growth and future projections warrant planning measures for both short and long-term mitigation strategies. Growth projections are based on several resources, since the last census was conducted by Israeli officials in 1967 (Roy 1995:9). Another source is the Palestinian National Authority, which has two statistics departments, the Central Statistics department of the Ministry of Planning and International Cooperation, and the 
Palestinian Central Bureau of Statistics. Yet, neither department has conducted a detailed population assessment. Another data source is the UNRWA which generally maintains a current listing of all refugees, who comprise a large percent of the Strip's population. All these developments, however, have similar, long-term projections.

The current population within the Strip's borders is estimated at approximately 960,000. About 75 percent $(720,000)$ are registered refugees; registered refugee statistics are based on birth and deaths reported to UNRWA's registration department (UNRWA 1996). About 400,000 of these refugees live in thirteen camps scattered around the Strip. There is an extremely high population density of approximately 2,500 per square $\mathrm{km}$ and up to 22,000 per square $\mathrm{km}$ in the refugee camps (Heiberg and Ovensen 1993, UNRWA 1996).

\section{Age Structure and Gender Composition}

The Gaza Strip population is extremely young. Almost 50 percent of the residents are under fifteen years old (see FIGURE 2) (Heiberg and Ovensen 1993). As the population pyramid shows, the balance is equal between men and women.

Areas with this pattern are typical of fast growing populations. Although the data for this are from a small sample of the population, it appears to represent the actual conditions in the strip. I walked many hours and through many areas of the Strip, and noticed how similar it was to walking around a crowded school yard during recess. 
FIGURE 2. POPULATION DISTRIBUTION IN THE GAZA STRIP, 1993

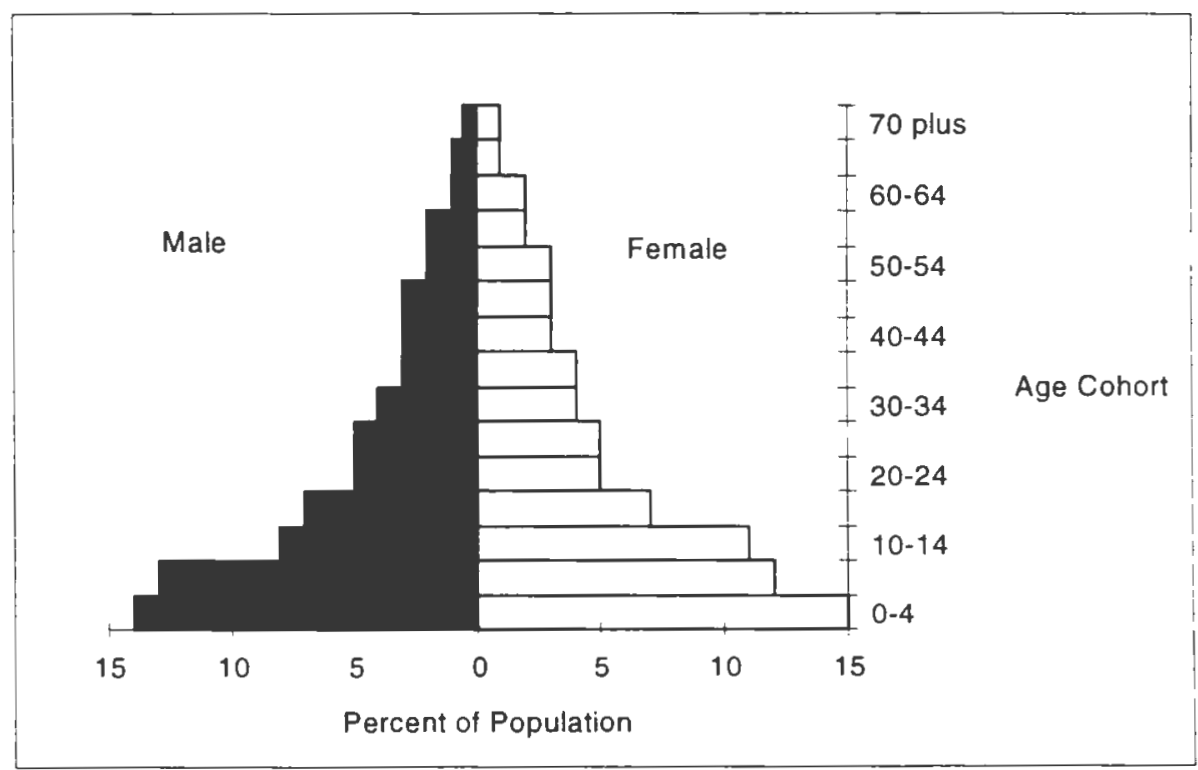

Source: Heiberg and Ovensen 1993

\section{Population Projections}

Population projections are generally based on the current population and historical rates of births, deaths and migration. However, due to lack of any useable detailed population data, discussed here are projections based on current growth rates and migration estimated by several agencies. Various alternative projections are reviewed with a discussion on their implications for development, and are summarized in FIGURE 3.

\section{Alternative Projection \# I}

In this scenario, population will continue with a growth rate of five percent for the next 20 years. The migration rate of returning refugees will remain the same, and the population will double by 2010 . 
FIGURE 3. POPULATION PROJECTIONS FOR GAZA STRIP, 1996 - 2020

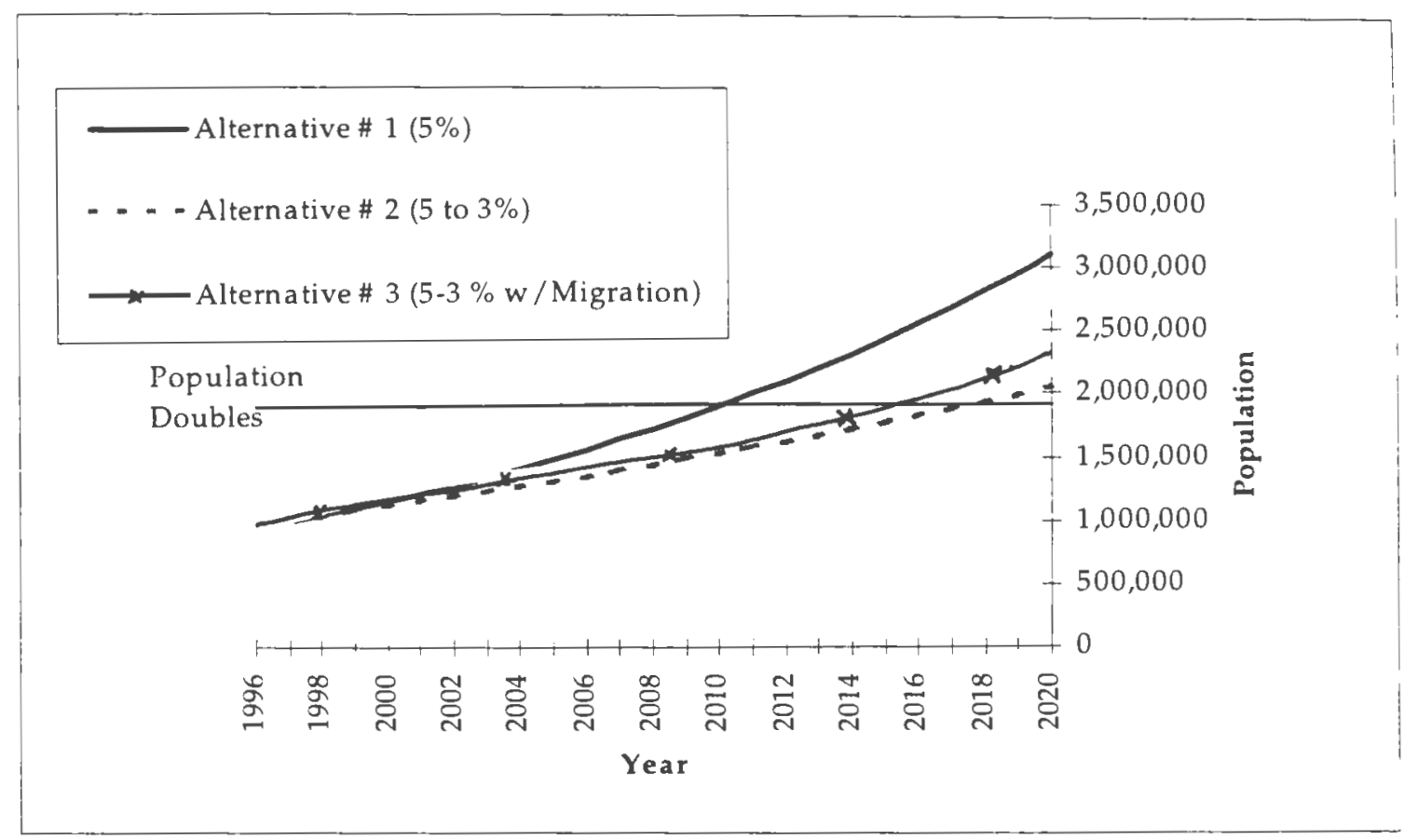

Source: MOPIC 1996, FAFO 1994

\section{Alternative Projection \# 2}

Under the next scenario, the population will continue with its current growth rate (five percent) for the next five years. The rate will fall over the following 15 years to a low of three percent. The decrease is due to a projected improvement in the economy which will in turn allow more women to work and reduce the number of births (Gronning 1996, MOPIC 1995b). The population would double by 2017 . Additionally, the migration rate will remain the same.

\section{Alternative Projection \# 3}

In this projection, the growth rate will decline from five to three percent over the next five years, and the population will double in 15 years. MOPIC (1996b) estimated that one- 
fifth of 500,000 returnees to Palestine will come to Gaza. Therefore, 100,000 returnees are added to the projection $(25,000$ per year) in the beginning of the trend over a four year period.

Regardless of which projection is used, the population will probably increase substantially over the next 10 to 20 years. This is confirmed from the projection by Heiberg and Ovensen (1993) estimating that the population will double within the next fifteen to twenty years (see FIGURE 3). A population increase of this magnitude will place an extreme burden on the resources and services that are already severely depleted and strained. Since there is a great demand for housing in Gaza, the gap between those who need housing and those who do not need or have housing will continue to increase.

\section{PLANNING PROCESS AND CHARACTERISTICS}

Current land use planning and development practices in Gaza today evolved over the past 75 years. Origins of these are laws range from the Ottoman Empire in the early 1900's to the present day Israeli-Palestinian Interim Agreement on the West Bank and Gaza Strip (1995). A brief overview of land ownership, laws, and institutional barriers that pertain to planning and more specifically to housing development in the Gaza Strip is presented next.

\section{Land Ownership and Land Use Planning}

Land ownership in Gaza Strip has been controlled by laws and ordinances rooted in the tradition of Moslem people who ruled this part of the world for many centuries. At 
present, a mix of laws from several rulers govern land ownership practices in Gaza. The Ottomans produced two pieces of legislation prior to the end of their rule in 1921: the Land Code of 1858 and the Civil Code of the same period. At that time, legislation concerning landed property was based entirely on the distinction between Moslems and unbelievers [non-Moslems] (Granott 1952:86). Since 1921, ordinances enacted through the British Mandate, Egyptian control, and Israeli Military Ordinances established more defined divisions of land.

The Gaza Strip comprises approximately $365 \mathrm{~km}^{2}$ of land (see TABLE 1). Israel controls approximately one-third of the land area, mostly in settlements along the south coast. The Palestinian government owns almost one-quarter of the land, and the most of the remaining area is under private ownership. Therefore, the Palestinians have access to about two-thirds of the total land area of the Strip. Some of this land is off-limits to development as will be discussed later in this chapter.

TABLE 1. LAND OWNERSHIP IN GAZA STRIP, 1995

\begin{tabular}{lrrr}
\hline \multicolumn{1}{c}{ Owner } & Amount $\left.\mathbf{( k m}^{\mathbf{2}}\right)$ & Square miles & Percent \\
\hline \hline Palestinian owned & & & \\
$\quad$ Palestinian Authority (government) & 97 & 378 & 27 \\
Private & 165 & 64 & 45 \\
$\quad$ Islamic Waqf & 7 & 3 & 2 \\
Total area available to Palestinians & 269 & 103 & 74 \\
\hline Israeli owned & & & \\
$\quad$ Settlements (private) & 88 & 34 & 24 \\
$\quad$ Government) & 8 & 3 & 2 \\
Total area available to Israelis & 96 & 37 & 26 \\
\hline Total Gaza Strip & 365 & 140 & 100 \\
\hline Source: Roy 1995, MOPIC 1995b & & &
\end{tabular}




\section{Past Planing in Gaza}

Planning regulations and ordinances in Gaza are based on legislation passed during the British Mandate in 1917, Egyptian rule during the 1950's and 60's, Israeli occupation between 1967 and 1994, and present civil rule of the Palestinian Authority. Town Planning Ordinance No. 28 of 1936 (TPO 28) was based on previous legislation, and subsequent changes relating to roads, buildings, and parcellation were made by Mandate and Egyptian Authorities in 1937, 1941, 1947, and 1961 (Atkins 1996:5-1). The Palestinian Authority has published one regulation based on TPO 28, which relates to multi-story buildings.

Israeli-prepared plans indicated that the basic planning policy of the Civil Administration was that urban development should be confined to land within Municipal and Village Council boundaries. During occupation, the Israelis issued numerous regulations or military orders. This type of planning was based on security measures which resulted in compact growth and highly urbanized areas.

Prior to occupation in 1948 , land along the Mediterranean Sea in Gaza was parceled into long, narrow strips (see FIGURE 4). This practice was also a common in Syria and Transjordan. According to Granott, parcels in an area near Gaza had a maximum length of 2000 meters, a minimum length of 400 meters, and minimum width of 10 meters. Some were a few kilometers long and a few meters wide, and many were landlocked. The reason for the multitude of fragmented properties is that "all heirs wanted an equal 
FIGURE 4. AGRICULTURAL LAND PARCELLATION NEAR GAZA CITY, PRE-1948

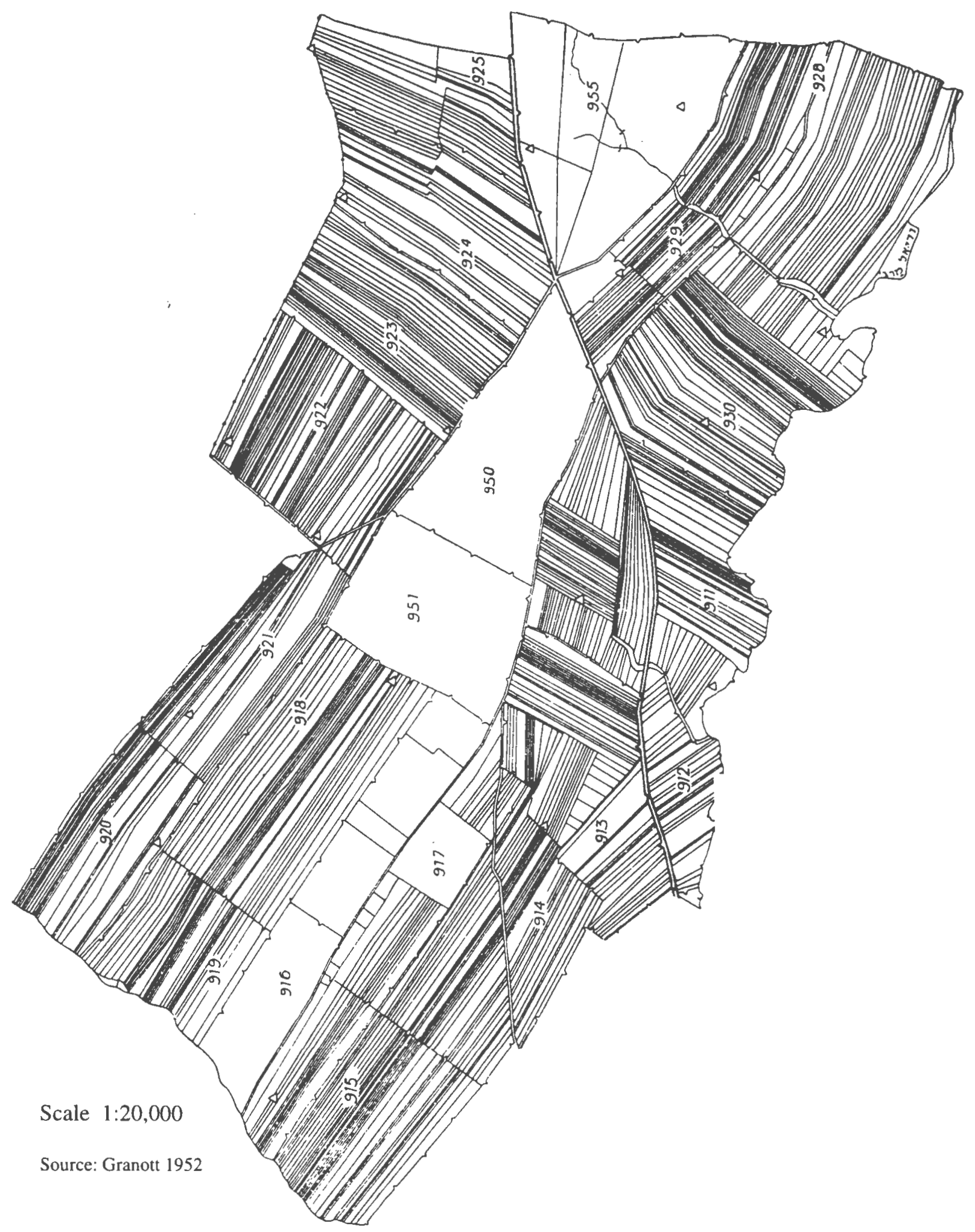


share of property for their inheritance" (Granott 1952:206), and there was no economic incentive to keep tracts of land together. Land at the time of parcellation was valued by villagers more than any other asset or kind of property, according to Granott (1952). This kind of land division, however, hampers tillage and is a great hindrance to progress of agriculture in the country. It takes no account of the topography of the fields and their natural features. Furthermore, it currently restricts development since it is generally necessary to have one large parcel to build new housing projects, and parcellation of land with many owners is a long process.

During Israeli occupation, there was a distinction in regulations between land use within the municipal boundaries and the land use outside in areas controlled by Village Councils. It was required that land in the villages was to be at least 25 dunams (approximately six acres) for a building to be built or obtain a building permit. Within the municipal boundaries, a minimum of five dunams was required. Since the change in administration in 1994, responsibility for land use now lies with the Palestinian National Authority's Ministry of Local Government. They reduced the minimum size for building outside the municipal boundaries to 5 dunams, thus facilitating development and making land use requirements consistent in and outside municipal boundaries.

\section{CURRENT PLANNING AND DEVELOPMENT IN GAZA}

Under the Palestinian Authority, planning is conducted by several ministries with primary effort and responsibility held by the Ministry of Planning and International Cooperation (MOPIC). Within this organization are two groups: the Directorate for Urban and Rural 
Planning and the Environmental Planning Directorate. They are both responsible for physical, environmental, and multi-sectorial planning for the Gaza District.

MOPIC recently prepared an Emergency Resources Protection Plan. It aims to protect vital resources in Gaza from ill-considered decisions on approving and siting environmentally sensitive development projects and programs. The plan is expected to have a life span of not more than three years by which a more comprehensive and longerterm development and land use plan will be implemented (MOPIC 1995a).

Comprehensive plans include other agencies, as well.

\section{UNRWA's Role in Planning}

The United Nations Relief Works Agency (UNRWA), the largest non-governmental organization in Gaza Strip, plays an important role in planning and providing social services and infrastructure. Since the peace agreement between Israel and the PLO, UNRWA drew up long-term project proposals to help implement the agreement. With donor funds, they built 24 new schools, 26 new playgrounds, a college of nursing, two new health centers, and repaired more than 3,500 houses for refugees. Work continues on building additional schools, sewage pumping station, and sewage/drainage schemes (UNRWA 1996). To the best of my knowledge, there are no formal joint development projects between MOPIC and UNRWA. UNRWA has traditionally taken care of the refugees and planned according to Israeli Military actions during occupation in the Strip. 
On a larger scale, regulations of the Israeli-Palestinian Interim Agreement restrict the Palestinian Authority to certain types of development and certain types of land uses. These restrictions may be changed when the Palestinian Authority and the Israeli government determine the final status of the Interim Agreement. A discussion of these restrictions follows.

\section{Constraints to Planning}

\section{Interim Agreement Restrictions}

Articles in the Israeli-Palestinian Interim Agreement (IP) developed in 1994, set forth many restrictions relating to security and civil affairs within the Gaza Strip (MFA 1995). The agreement addresses security issues regarding land-use practices and uses, especially near borders and Jewish settlements (see Appendix 1 for specific text). The articles of the agreement provide the rationale, context, and perspective on the spatial pattern of permitted land uses, locations, and activities in the Gaza Strip.

The IP specifies security arrangements in the Gaza Strip by designating specific areas and restrictions (see FIGURE 5).

- The Delimiting Line creates the borders of the Strip.

- Inside the border is the Security Perimeter which restricts the use of firearms, and limits the type and amount of building.

- Israeli settlements and access roads are to remain under Israeli Military protection.

- Israeli and Palestinian military forces will maintain joint patrols in the Yellow Area.

- The Palestinian Authority will have civil control in the Yellow Area as well (Annex I, Article VI, MFA 1995). 
FIGURE 5. ISRAELI - PALESTINIAN AGREEMENT MAP

Map No. 2 Security Arrangements on the Gaza Strip

(appearing orignially as Map No. 1 of the Gaza - Jericho Agreement)

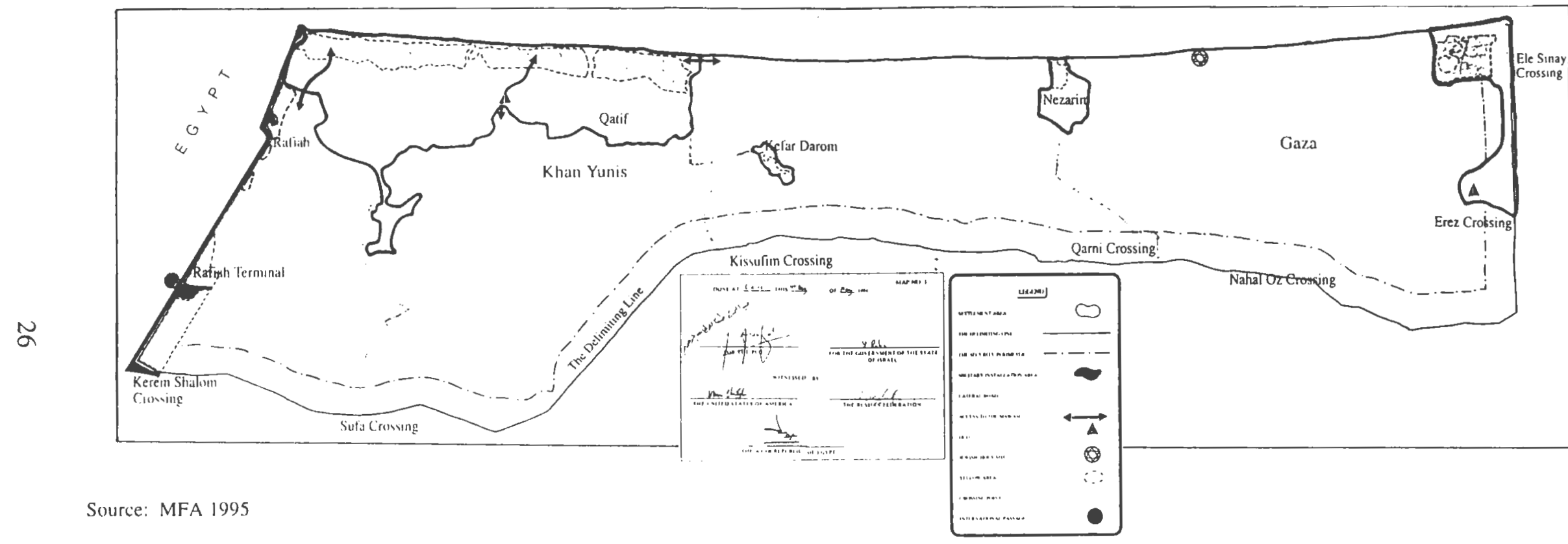

Source: MFA 1995 
Specific land use regulations near property owned or used by Israelis is as follows:

- Density and setbacks are defined by the IP.

- Existing buildings within 100 meters of the Delimiting Line shall not be altered.

- New buildings in the area between 100 and 600 meters of the Delimiting Line and within the Yellow Area shall be limited to one unit per 6 acres and shall not exceed two floors.

- The Palestinian Council shall maintain the agricultural character of the remaining areas of the Security Perimeter.

- Buildings shall not be constructed within 75 meters of the lateral roads (Israeli controlled roads to the settlements).

Any proposed waste disposal sites, sewer treatment plants, or power stations will have to be approved by a joint Israeli/Palestinian board.

The demands of the IP restrict development of a large amount of land. They essentially prohibit changes in any land use within 600 meters of the border. The Security Perimeter alone, which lies 600 meters from the Israeli and Egyptian borders comprises about 36 $\mathrm{km}^{2}$ (14 square miles), or ten percent of the land in Gaza Strip. This amount does not even include the settlement areas. These constraints will be discussed further in Chapter Five.

The Articles express the need to protect Settlement areas by ensuring that nearby construction will cause no harm to them or damage the infrastructure serving them. Furthermore, it appears that security issues prevent any changes to existing land use activities as well as any future activities along the border. 


\section{SUITABILITY ANALYSIS FOR NEW HOUSING}

Developers and governmental planning agencies generally determine areas for new residential development. Both planners and developers would like to make more effective and informed land use decisions in the land development process. The first step in this process is to determine where to locate a site and why. In this section, there will be a discussion of methods for siting new residential areas to provide background for a new/ refined suitability analysis as detailed in Chapter III.

Researchers have proposed different methods and models to determine the most suitable areas to develop multi-family homes for existing and future residents. Since computers became useful planning tools in the 1960 's, approaches to processing information, analyzing land uses, and aiding decision making have increasingly relied on them.

\section{Methods}

Decision-based methods of planning for housing locations rely on identifying land uses and conditions, coding them into a database, linking these databases, and then analyzing their information. Geographic information systems (GIS) incorporate this method and allow users to visually observe and analyze land use data bases. One method, for example, "incorporates a GIS to assemble, manage, display, and make available millions of pieces of information describing land development potential" (Landis 1995: 454).

Another method, residential suitability analysis, identifies the best locations for residential development based on location standards or attributes (Kaiser et al. 1995). 
McHarg (1992) first used this method to derive a suitability map from a set of physical factors (e.g., soils, slope, vegetation, land use). It involves mapping related attributes of land areas that are favorable for residential development across a region. Attributes are ranked according to their contribution to suitability and then combined to form a composite map. Even though residential suitability analysis is a systematic tool, it reflects local judgment of current conditions and trends within a regional context.

\section{Models}

Some GIS applications use a discretized continuous field or raster model. A grid pattern is placed over each attribute and then each cell is coded according to its suitability. Layers of attributes are combined or overlaid on each other to form a suitability map (Burrough 1995) (see FIGURE 6). A similar model of using layers is the linear combination model (Hopkins 1973) (see FIGURE 7). With this model, the suitability rating for a particular region is determined by summing the ratings of individual attributes.

Other researchers rely on models that use spreadsheets and computer programs, or one of the two, to produce tabular data or graphical representations of the data. Kaiser and Weiss (1970) proposed a decision-based discriminant model for single-family homes in the United States in response to local public policies that affect decisions. Their model incorporates current preferences and values of physical, location, and institutional characteristics to determine probabilities and spatial distributions of future residential areas. 
FIGURE 6. DISCRETIZED CONTINUOUS FIELD MODEL
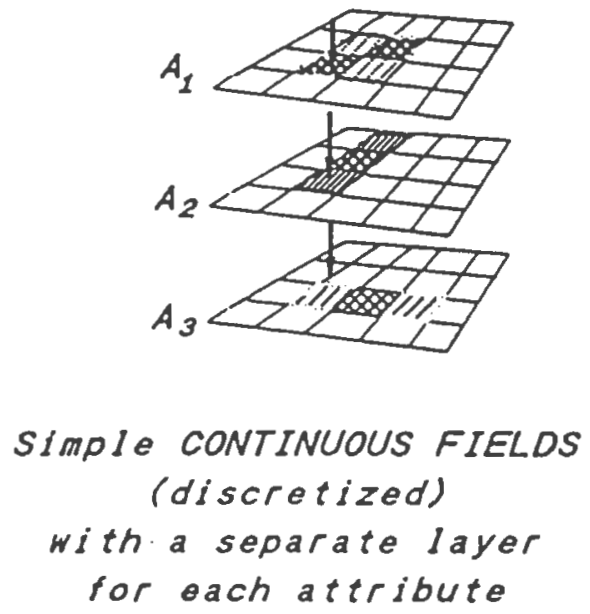

Source: Burrough 1995

FIGURE 7. LINEAR COMBINATION MODEL
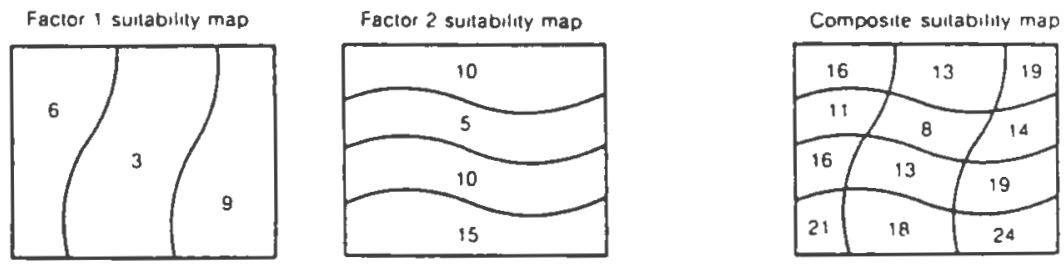

Source: Hopkins 1997

\section{Suitability Analysis}

Appropriate planning for land development incorporates one or a combination of several types of techniques. These techniques require an assessment of present land use activities and designing a plan or vision of future uses. Suitability analysis determines levels of 
suitability for particular land areas based on constraining as well as accommodating factors (Kaiser et. al. 1995). Without suitability analysis, land may not be put to its best use.

Suitability analysis is typically appropriate for regional planning of specific land use categories, but it scales down to individual sites. It is only one of several land use categories of a land use plan that MOPIC could use to determine whether or not they should develop a particular area of the Strip for housing developments. Other land use categories include commercial and industrial areas, and community infrastructure (schools, mosques, government buildings). At the local or municipal level, parcels or groups of them should be developed according to site-specific criteria as well. These criteria include housing design, density, and compatibility with existing land uses. For more advanced planning, more detailed information is needed. These may include a recent census, soil maps, and specific cropland uses. 


\section{ChaPTER III. Methodology}

OVERVIEW OF METHODOLOGY - LAND USE ANALYSIS AND ASSESSMENT

While working at the Ministry of Planning and International Cooperation (MOPIC) in Gaza City, I utilized computers, a small library, and other resources in the office to compile available data and information, and derive this methodology. Although a Norwegian consultant advised MOPIC on how to use a geographic information system (GIS), there was insufficient data to use a full-scale GIS for my research. Given these extreme limitations, I designed a raster-based GIS model, as explained above, using a Microsoft Excel spreadsheet. This technique provided a good platform developing the suitability analysis for residential developments.

There are two goals of this methodology:

- Determine the most suitable areas for future residential development in Gaza Strip.

- Determine areas that should not be developed.

\section{Project Method}

In this study, I will combine McHarg's suitability analysis and the residential suitability methods, in addition to the discretized continuous field model (McHarg 1992). This combined method provides an appropriate analysis for this project. The complementary characteristics of factors, layers, and spatial segregation allow me to input data into a spreadsheet, and then assign it to a grid pattern that represents the shape of Gaza Strip. Second, this method focuses on attributes needed by residents under the constraints in 
Gaza rather than depending on preferences and values in a market-based system used by Kaiser and Weiss (1970). Third, the use of full-scale GIS is only possible if enough quantifiable data are available to the user and are in an applicable format. During my internship in Gaza Strip, data sources were limited to a topographic map, an altered aerial photograph, personal observations, communication with residents, and an a limited number of environmental and social studies. Information sources from my research outside Gaza were limited as well: most studies and reports focused on Israel and on the Middle East. Since data were limited, a traditional GIS approach was not applied to this project.

Even without GIS, this combination of methods and models allows me to systematically determine suitable housing locations in Gaza. It involves coding attributes in a tabular form, and then mapping them on a grid-based cell pattern on a Microsoft Excel spread sheet. This method is based on a distributive model, one that spatially distributes data across cells that form a map of the study area (Burrough 1995).

\section{Limitations of Suitability Analysis Methods}

This suitability analysis provides a good approximation of locations siting residential development. However, there are several limitations to be carefully addressed in this analysis. One of the limitations with suitability analysis is the pattern and location of recommended suitable sites. If the present development pattern is characterized by compact growth around urban centers, and the analysis results in a scattered pattern of sites throughout the Strip, then this reveals shortcomings in the model's attributes. The 
attributes would be either inappropriate or they would reflect a highly distributed pattern of attributes in the Strip.

The values applied to specific factors, such as proximity to roads and city services is another limitation experienced in this analysis. Selecting and assigning importance to the factors is key to an appropriate analysis. Without this information, decision makers may direct development into an undesirable growth pattern.

\section{Determination of Land Use Attributes}

Procedures utilized for evaluations in this analysis rely on a set of land use attributes. Due to the limitations of data, only a few attributes that could help determine housing locations were utilized. Attributes were chosen on apparent needs of local residents, which included mobility, clean water, and access to markets.

I derived information from meetings with local planners, literature about the social lives of Palestinians in Gaza, and two months of personal observations while living in Gaza Strip. I worked with about 10 local planners and three Norwegian advisors. We met at least twice a week to express concerns and future plans in the Strip. I attended several meetings about coastal, population, tourism and recreation, transportation, and environmental issues. Population growth impacted most other sectoral plans, and without a recent census, planning for the future became difficult. 
I read literature about past and future projects in Gaza. The FAFO Report: Palestinian Society (1994), provided a wealth of information. This was the only major study in Gaza regarding housing, work, education, and gender issues,. There were other reports on future projects, such as an environmental impacts assessment for a proposed Gaza port, which provided additional perspectives to the anticipated growth patterns.

I also spent many hours observing land use activities all around the Strip. Through agricultural and urban areas, I walked, rode a bike, and drove a car. Much of the area appeared undeveloped, but new housing is mushrooming outside municipal boundaries.

One meeting with the Mayor of Khan Younis, a consultant from England, and a Norwegian advisor at MOPIC gave me much insight to established planning practices. The consultant presented a plan that included growth phasing. The mayor was not familiar with this concept: the city administrators relied on a master plan from the 1940's and many of the laws from past governments. It will be difficult to implement new planning concepts in these types of communities unless there is more education and fewer constraints to development.

These personal experiences at the street level helped me learn about many local planning issues. Without local knowledge of Gaza, I could not have applied these attributes to the methodology. 
I utilized six attributes to evaluate the suitability housing. Each attribute had a criterion which assisted in the analysis. The first two attributes relate to the environment (see TABLE 2). I chose "Areas near environmental features or concern" because a resource was either scarce (e.g. Wadi Gaza) or there was strong dependence on its use (e.g. the coastal beaches). "In/out of Resource Protection Zone" represented any areas within natural conservation, agriculture, and water zones that are protected and highly restricted according to the Emergency Resource Protection Plan (MOPIC 1995a).

\section{TABLE 2. LIST OF ATTRIBUTES USED IN THIS STUDY}

\begin{tabular}{ll}
\hline \multicolumn{1}{c}{ Attributes } & \multicolumn{1}{c}{ Final Criteria } \\
\hline 1. Areas near environmental features of concern & Scarce strong dependence on a natural resource \\
2. In/out of Protected resource zones & Restricted conservation, agriculture, and water areas \\
3. In/out of urbanized area & Development only by infill in urbanized area \\
4. In/out of municipal boundaries & More restrictive development regs outside boundary \\
5. Proximity to major city services & Residents' needs based on observations \& other info \\
6. Proximity to main transportation & Residents' dependence on transportation to services \\
\hline
\end{tabular}

Since urbanized areas are densely built and can not be developed except with limited infill development, I determined whether or not an area is in an urbanized zone. A more detail analysis, however, should address infill areas.

Municipal boundaries have had different density restrictions during the Israeli occupation: less dense development allowed outside the municipal boundaries than inside. This practice resulted in compact development within the boundaries and practically no urbanization outside them. For this reason, I determined which areas were inside and outside these boundaries. 
The only public transportation service within the Strip is with taxis. Other modes include private automobiles and donkey carts. Areas that are close to main roads provide more opportunities for people who work in the main cities. Therefore, I ranked areas by their proximity to main transportation routes.

I also ranked areas by their proximity to city services or places that people frequent on a daily or weekly basis. These may include places of employment, government offices, and markets.

\section{METHOD}

The method for determining suitable areas of residential development areas involves the seven steps listed below:

1. A grid pattern of one kilometer $(\mathrm{km})$ blocks was laid over a map of Gaza Strip, which contains $365 \mathrm{~km}^{2}$ of land. Each block that laid over at least part of Gaza Strip was numbered (see FIGURE 8). A total of 428 blocks for this map was designated in conjunction with work by the Directorate of Urban Planning.

2. For each block, scores were recorded based on attributes assigned to cells on the spreadsheet. Information on each cell was obtained from Map No. 1 of the Agreement on the Gaza Strip and the Jericho Area, planning personnel, library resources, and personal observations. I grouped these attributes into two priorities:

First Priority:
A. Israeli Settlement Area
B. Security Zone 
FIGURE 8. MUNICIPAL AREAS AND GRID OF GAZA STRIP

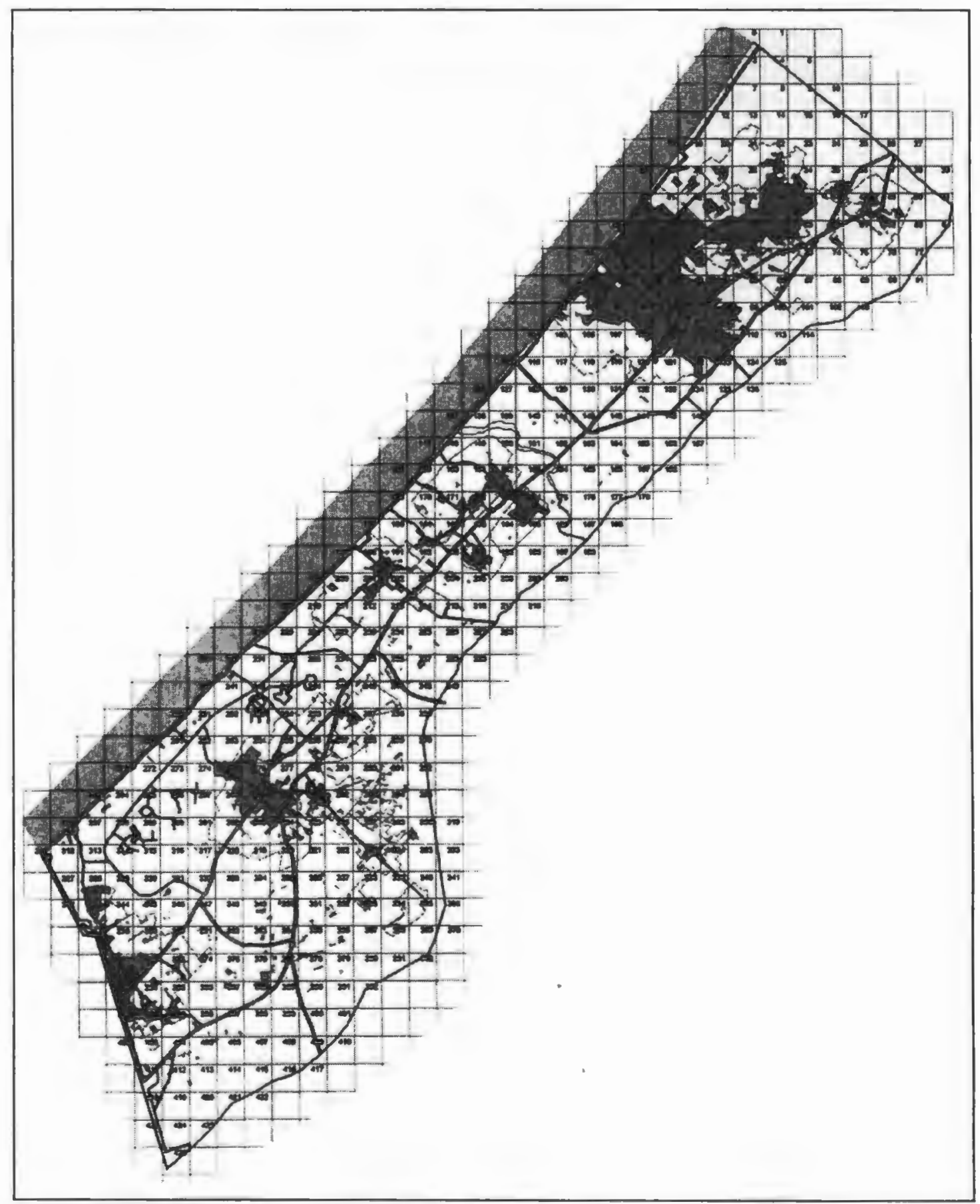

Source: MOPIC 1996 
C. Israeli Military Installation

D. Yellow Area

E. Industrial/airport area

Second Priority:

A. Proximity to transportation Score on major transportation

B. In/out of municipal boundary

in

out

C. In/out of Emergency Resource Protection Plan boundary

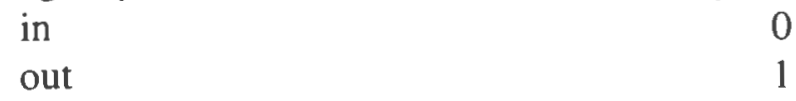

D. Proximity to major town services

in built-up area (BA) 0

within one kilometer BA 1

greater than one kilometer BA 2

E. Cells adjacent or on areas of environmental concern

$\begin{array}{ll}\text { no major concerns } & 0 \\ \text { coast } & 1 \\ \text { flood area } & 2 \\ \text { river } & 2\end{array}$

3. Any block that did not have at least ten percent of it within Gaza's border (e.g., cell 91) was not used. All blocks that contained at least fifty percent of one of the First Priority areas were removed from further assignment of attributes since they could not be developed according to the IP. For example, if a block was located in a Military Installation, it was put in to a "Restricted" category and did not receive a score.

I assigned numbers to the remainder of the attributes in the following manner: 
4. Each attribute was ranked and scored depending upon its contribution to suitability of residential development (Second Priority criteria). For example, a block that is mostly (greater than 50 percent) within a municipal boundary is scored "0", while a block outside is scored with a " 1. "

5. The cumulative number of each block's criteria was reclassified into a composite score.

6. All blocks were ranked according to their numeric scores, grouped according to their suitability, and colored accordingly (see TABLE 3).

TABLE 3. SUITABILITY RANKING

\begin{tabular}{ccc}
\hline Cumulative Block Score & Rating & Color \\
\hline \hline $0-1$ & Most Suitable & Dark Blue \\
$2-5$ & Suitable & Light Blue, Green \\
$6-8$ & Least Suitable & Grey \\
$>=9$ & No Build & Red \\
-1 & Restricted & Yellow \\
\hline
\end{tabular}

Blocks with the lowest score are most suitable, while blocks with the highest score are least suitable. Restricted blocks $(-1)$ are colored yellow.

7. Grid lines (rows and columns) were arranged on an Excel spreadsheet to resemble square cells of the grid pattern. In each of these cells, formulas were written to yield the cumulative block score. A macro program was written in the spread sheet to yield a cell color that represented the cell's cumulative score.

The final suitability map is a composite of all block numbers and their representative colors (see FIGURE 9). The map of urbanized areas and municipal boundaries was overlain onto this final composite map (FIGURE 8). The final map indicates that the 
FIGURE 9. COMPOSITE MAP FOR ALL RESIDENTIAL LOCATIONS

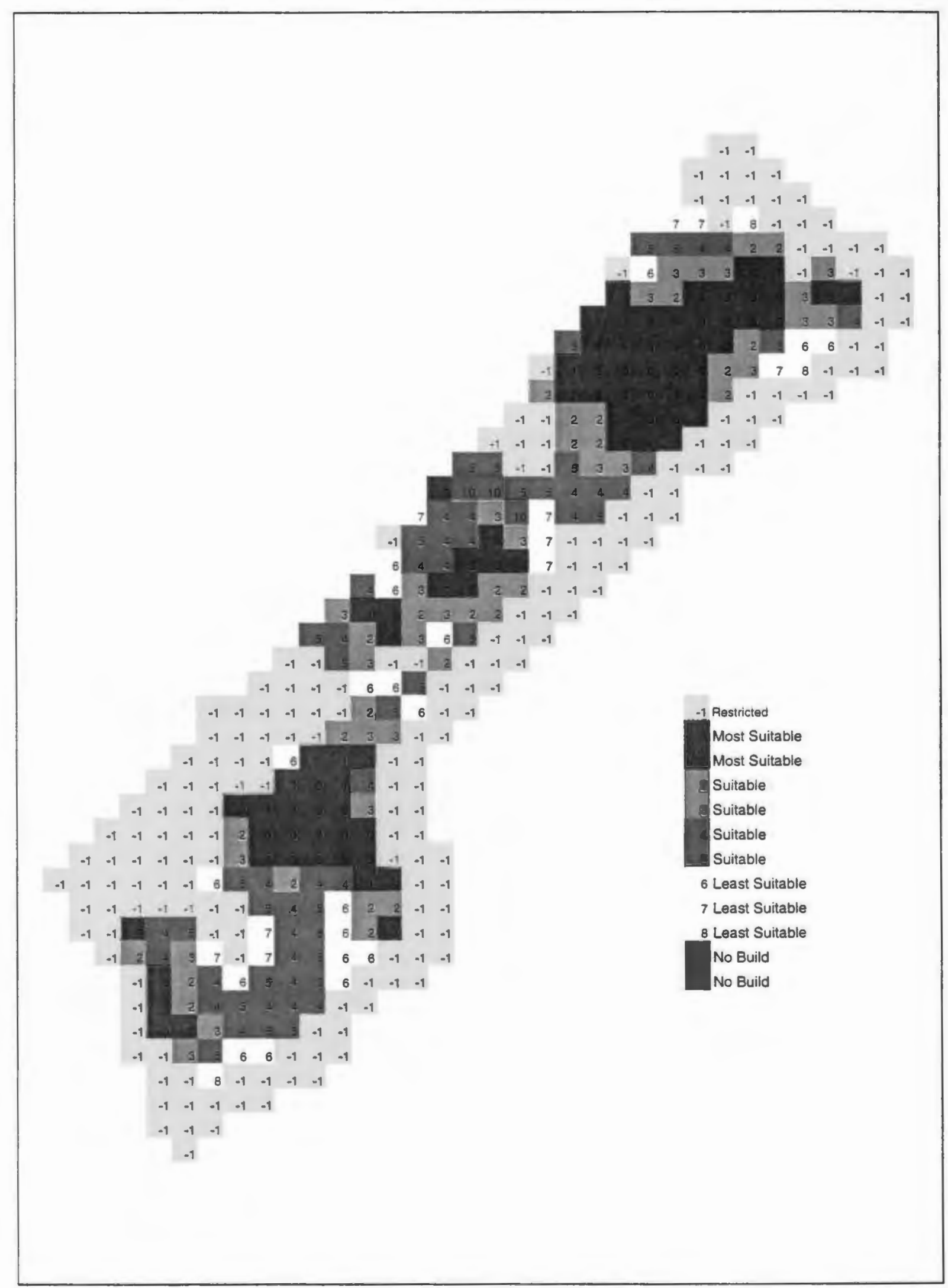


resulting most suitable blocks not in urbanized areas and within municipal boundaries provide ideal locations for residential development (e.g. cell 120). This impact of these locations will be discussed in the analysis and conclusion sections.

\section{CONDITIONS FOR METHODOLOGY AND ASSESSMENT}

The grid laid over Gaza Strip results in 428 square-kilometer blocks. Since 30 of the blocks had a substantial portion (greater than $90 \%$ ) outside the Gaza Strip border, they were not assessed. An additional 98 blocks were excluded from the analysis because they do not permit medium or high-density residential development per the lsraeli-Palestinian Interim Agreement. These blocks mainly include security areas, settlements, proposed airport and industrial zones, and military installations, as I explained earlier in the Constraints to Planning section (Chapter Two).

For the purposes of this study, residential development consists of housing projects that contain ten or more dwellings (units). This definition coincides with the requirements of the Environmental Resources Protection Plan which regulates major development projects in Gaza Strip (MOPIC 1995a:16).

\section{HOUSING NEEDS}

For this study, I will compare the housing needs based on previous reports with the available capacity of the most suitable areas for development in Gaza This will be done in with the following steps: 
1. Determine the number of dwelling units (du) needed based on available needs estimates and projections.

2. Determine the gross densities (du/acre) according to present densities of cities (excluding refugee camps).

3. Calculate space required by dividing the number of units by the density.

4. Compare the space required to the amount of land suitable for development.

From these steps, housing needs and density levels will be discussed in relation to the most suitable areas for development. The amount of land needed for services, such as schools and roads, will also be included. 


\section{Chapter IV. ANAlysis}

\section{INTRODUCTION}

The analysis of Gaza Strip resulted in defining the level of suitability for residential development suitability levels. The composite scores identified the most and least suitable areas. In this chapter, I will explain the results and impacts of the analysis. The next chapter will describe the Implementation and Constraints of determining locations for housing developments.

Depending on their location, development of some areas may have to be phased in, as performed in other growth management strategies (Nelson and Duncan 1995). Of course, the first areas to be developed will depend on other factors, such as the availability of land and current economic situation of the Gaza Strip.

\section{SUITABILITY LEVELS}

This analysis of Gaza Strip has identified five residential development suitability levels:

1. Most suitable

2. Suitable

3. Least suitable

4. No-build

5. Restricted

The most suitable areas for residential development are divided into two groups by location, urbanized and non-urbanized. The most suitable areas with the highest potential 
for future development lie in non-urbanized zones since they are not yet developed. Of the 50 blocks that are deemed most suitable, 19 are outside urbanized areas (see FIGURE 10). The blocks north of Khan Younis and near the El Muntar section of Gaza City are prime areas for residential development. They are adjacent to urbanized areas, near major transportation routes, in the municipal boundaries, and are not located near areas of environmental concern. The most suitable areas in urbanized zones should be reserved for infill development.

Suitable areas are located on the outer fringes of urbanized zones and along major transportation routes. They could be developed but should be phased in after the most suitable areas. Phasing development prevents areas from being developed until existing areas fully utilize services, such as sewers and roads. The cost of new infrastructure would strain city revenues if developments did not fully utilize the infrastructure of the most suitable areas which are generally closer to city infrastructure of water and sewer lines, and roads. Phasing will also be discussed as part of the implementation plan.

The least suitable areas have attributes similar to those of the no-build areas. Most of these are in the rural parts of Gaza Strip, such as the area southeast of Khan Younis. They could be developed but only if developers adhered to environmental regulations and if the municipalities could finance the associated costs of services, such as schools and drinking water. 
The no-build level contains areas that are located far from major public services and/or are of significant environmental concern. Most of these areas are adjacent to the Wadi Gaza. They should not be developed due to the cost of providing services and the monetary and social costs imposed by environmental degradation. For instance, land use practices that add impervious areas and contribute urban runoff prevent surface water infiltration to groundwater. This reduces the already limited supply of drinking water and increases the costs of extracting water from deeper wells. The social cost of developing environmentally sensitive areas near the Strip's only river or the beach, would reduce areas for recreation since most Gazans face severe travel restrictions outside the Strip.

Restricted areas prevent any major housing developments. As mentioned earlier, only one building per six acres would be allowed in these areas (see Planning Constraints, Chapter 2). These buildings are also limited to two floors and 180 square meters (1938 square feet) per floor.

\section{PHASING}

Residential development plans should include a phasing component. The use of this planning tool requires that a specified area become fully developed at a pre-determined density before other areas are phased in according to a plan. Furthermore, development should not be allowed at time when the necessary public services and infrastructure can not be adequately funded. For example, if many housing projects were built over a large area, the costs of providing water and sewer services would be more expensive than if denser projects were built first. 
FIGURE 10. MOST SUITABLE LOCATIONS WITHIN MUNICIPAL BOUNDARIES

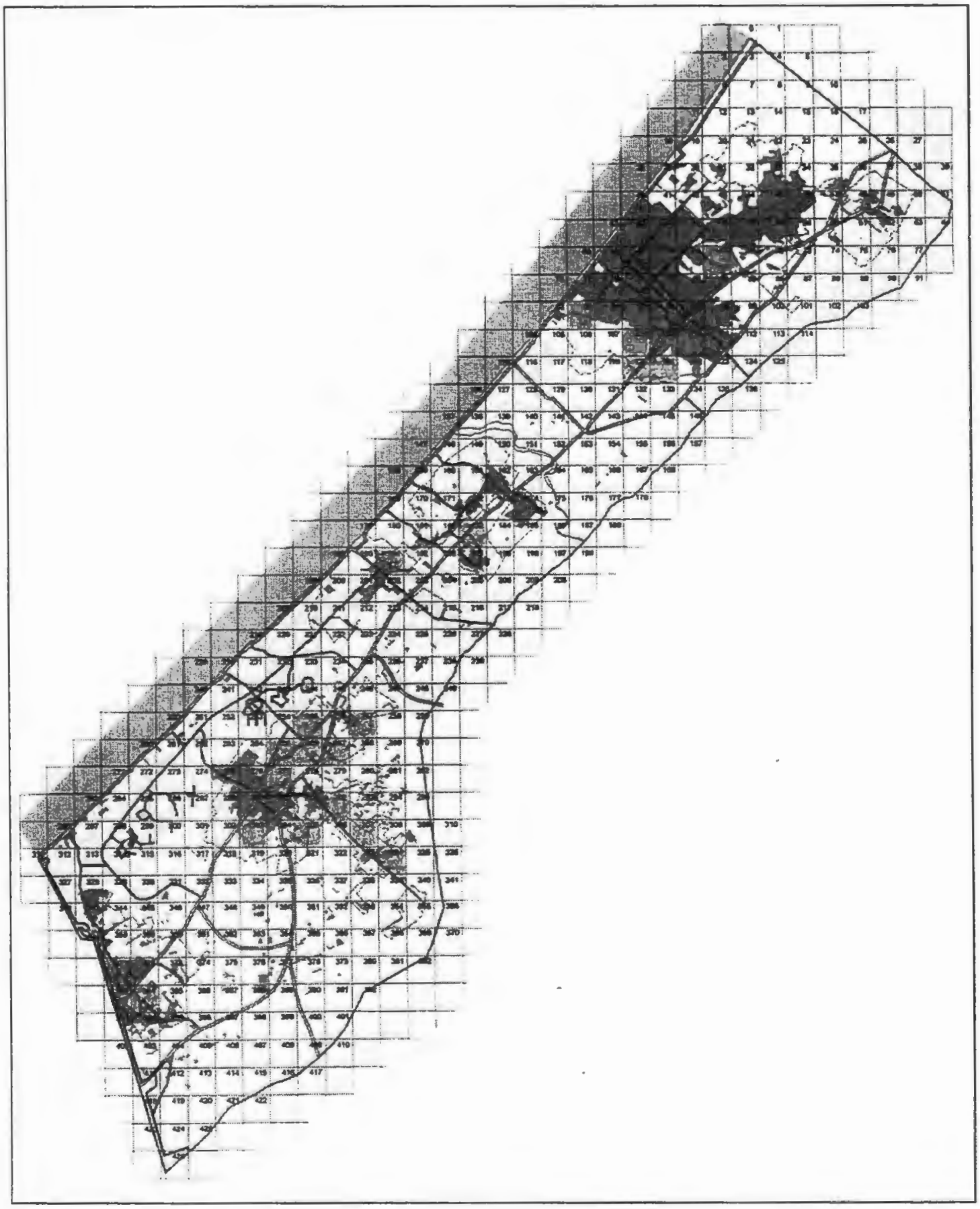


Each of the suitability levels mentioned above should be phased. Development of the most suitable areas before others would result in a more cost-effective delivery of public services and more efficient land development patterns.

Suitable areas should be investigated for future development, and may depend on sitespecific criteria. They may be developed if environmental impacts can be mitigated and public services adequately funded. The land between Deir El Balah and Nuserat is a good example of these potential blocks.

\section{FINDINGS}

Several levels of suitable areas for residential development are identified in this analysis. The most suitable areas are near the main cities of Gaza Strip. Of these, the most suitable areas in non-urbanized zones have the highest potential for development and should be developed first. They provide the most public services necessary for residential development and would cause the least environmental harm.

Areas identified as suitable could be phased in at a time when the cost of public services are adequately funded and the environmental impacts mitigated. No build areas should be restricted from all development plans. The environmental degradation and the infrastructure costs would prohibit large scale projects in these areas. 


\section{TOTAL NEED AND DENSITY LEVELS FOR NEW DEVELOPMENT}

To fully estimate the suitability of housing locations in Gaza Strip, housing needs and densities will be discussed. The amount of dwelling units (du) needed for the Strip over the next fifteen years and the locations for these amounts will be determined

The Ministry of Planning and International Cooperation (MOPIC) established standards for new neighborhoods units or villages to meet the needs of Palestinians in Gaza (MOPIC 1995b). These villages/ neighborhoods would contain schools, open space for private gardens, public service and administration buildings, and recreational areas (see TABLE 4). Dwelling units would house the average family size of seven persons and contain a lower floor for parking and services, three floors for living area, and a common roof terrace.

TABLE 4. LAND NEEDED FOR NEW RESIDENTIAL NEIGHBORHOOD

\begin{tabular}{|c|c|c|}
\hline Function & Land needed (acres) & Land use (percent) \\
\hline Housing & 24 & $53 \%$ \\
\hline Total Public Services & 7 & $16 \%$ \\
\hline Schools & 6 & \\
\hline Public Services, Administration, and Mosques & $I$ & \\
\hline Infrastructure & 4 & $9 \%$ \\
\hline Recreational Areas & 10 & $22 \%$ \\
\hline Total Land & 45 & $100 \%$ \\
\hline
\end{tabular}

Approximately 80,000 du will be needed to accommodated the expected increase of 560,000 in the population by 2010 . At seven people per unit, there are $80,000 \mathrm{du}$. With a density of $8 \mathrm{du}$ / dunam (32 du/ acres), 10,000 dunams (2,500 acres) would be needed for housing alone. An additional 8,868 dunams (2,217 acres) of land for recreation, 
infrastructure, and public service areas is also needed. Therefore, a total of 18,868 dunams ( 4,717 acres) of land are needed for new housing developments.

\section{LAND NEEDS AND MOST SUITABLE LOCATIONS}

From the preceding discussion, you can see there is large amount of land required to meet the future population growth in Gaza Strip by 2010. The most suitable blocks should be utilized to meet this demand. Each block of one square kilometer $\left(\mathrm{km}^{2}\right)$ is equivalent to 247 acres. Therefore, approximately 20 blocks will be needed to meet the future housing demand.

In the analysis, 19 most suitable blocks for future housing developments were selected. All of them are within the municipal boundaries and are not yet urbanized. These blocks should be evaluated first in the housing development process. The selection of these particular blocks, however, should not be randomly picked during the planning period from 1997 to 2010. They should be selected according to a growth management strategy which will be discussed in the next chapter. 


\section{Chapter V. ImPlementation AND CONSTRAints}

Housing should be thought of as a bundle of services rather than simply a place to reside. The quality and access to urban services greatly influence the actual and perceived utility that a family derives from the housing unit (IBRD 1993). Therefore, more than one planning agency should collaborate and determine the location of housing units. These agencies would determine housing needs, demand, supply, affordability, and other housing related services. This chapter discusses 1) several goals and the necessary planning tools to implement new housing development in the most suitable locations, and 2) constraints to implementation.

\section{IMPLEMENTATION}

Several goals and planning tools can implement proper growth strategies for new housing development in Gaza Strip. These goals include compact growth, parcellation, and contiguous development. TABLE 5 summarizes key features of the goals, tools and methods, responsible parties, and time periods for action during the planning period from 1997 to 2010.

Previous Israeli policies during occupation controlled and limited growth in Gaza Strip. However, adherence to many regulations has been scant or non-existent in spite of recent negotiations allowing autonomous civil control in the Strip (MOPIC 1995b). Several draft master plans have been prepared, but none of these were ever implemented (MOPIC 1995b). As a result, formal land use regulations are not currently practiced. Gaza City, for instance, lacks formal zoning regulations. MOPIC and other governmental agencies 
TABLE 5. IMPLEMENTATION GOALS

\begin{tabular}{|c|c|c|c|}
\hline Goals & Planning Tools & Responsible Agency & Time Frame \\
\hline \multirow[t]{3}{*}{ Compact Growth } & Urban Service Areas & $\begin{array}{ll}\text { - } & \text { Palestinian Authority } \\
\text { - } & \text { MOPIC } \\
\text { - } & \text { Ministry of Housing } \\
\text { - } & \text { Village Councils } \\
\text { - } & \text { Ministry of Local Governments } \\
\end{array}$ & $1997-1998$ \\
\hline & Adequate Public Facilities Ordinances & $\begin{array}{ll}- & \text { MOPIC } \\
- & \text { UNRWA } \\
- & \text { Municipal Councils } \\
\end{array}$ & $1997-1998$ \\
\hline & Infill Development & $\begin{array}{ll} & \text { Palestinian Housing Council } \\
\text { - } & \text { Municipal Councils } \\
\text { - } & \text { Ministry of Local Government } \\
\end{array}$ & $1997-2010$ \\
\hline \multirow[t]{2}{*}{ Contiguous Development } & Phasing & $\begin{array}{ll} & \text { MOPIC } \\
\text { - } & \text { Ministry of Housing } \\
\text { - } & \text { Palestinian Housing Council } \\
\text { - } & \text { Municipal Councils } \\
\end{array}$ & $1997-2010$ \\
\hline & Streamline Permit Process & $\begin{array}{ll}\text { - } & \text { Municipal Council } \\
\text { - } & \text { Ministry of Local Governments } \\
\end{array}$ & $1997-1999$ \\
\hline \multirow[t]{3}{*}{ Parcellation } & Zoning Ordinance & $\begin{array}{ll}- & \text { MOPIC } \\
\text { - } & \text { Ministry of Housing } \\
\text { - } & \text { Ministry of Local Government } \\
\text { - } & \text { UNRWA } \\
\end{array}$ & $1997-1999$ \\
\hline & Reduce Restrictive Development & - $\quad$ Municipal Governments & $1997-1999$ \\
\hline & Land Readjustment & $\begin{array}{l}\text { - } \text { Private Land Owners } \\
\text { - Municipal Governments } \\
\text { - } \quad \text { MOPIC } \\
\text { Central Committee for Building and City } \\
\text { Management }\end{array}$ & $1997-2010$ \\
\hline
\end{tabular}


recognize the need to develop goals that could foster housing developments. The following goals should aid their planning process.

\section{Compact Growth}

New housing developments in Gaza should not only provide a home to families, they should also provide efficient delivery of services, prevent the waste of scarce resources, reduce the need for expansion of transportation capacity, prevent costly or conflicting land use patterns, and minimize public facility costs (Nelson and Duncan 1995: 13). Growth management planning in the United States has shown the benefits of implementing an urban growth strategy, which includes compact growth, to resolve these similar issues. Oregon's state-wide growth management program has improved the government's delivery of services, consumed less land, and provided more households with better access to various modes of transportation. Jurisdictions in another high growth state, Florida, relied on their comprehensive plan to manage growth, which resulted in more efficient use of infrastructure.

Planning at the metropolitan level (rather than at the state level) can be compared to urban planning in Gaza. An urban service area was established in Sacramento County, California. It specified limits for water and wastewater extensions, and denied development requests on the basis of high costs of services in outlying areas. The Cape Cod Commission in Massachusetts guides development, preserves important environmental features, and manages urban development patterns. These growth 
strategies provide effective means for managing land in an efficient manner that can be used as examples for Gaza.

Implementation of a compact growth strategy for Gaza requires three tools or methods particular to the area in question (see TABLE 5). They include urban service areas, adequate public facilities ordinances (APFOs), and infill development. Urban service areas around the urbanized centers of Gaza City, Khan Younis, and Rafah, would direct development into the cities and preserve the outlying areas for agriculture and other open space uses. Essential public infrastructure would not be extended to land outside the urban service area. An urban service area would direct new housing developments from outlying areas to more centralized urban areas. High density development would also be encouraged within the urban service areas by parcellation, and permit streamlining policies discussed below.

The Strip already has severe deficiencies in existing infrastructure. Additional development without adequate public facilities would exacerbate this problem. Implementation of ordinances to ensure that public facilities are built and are on line to provide a minimum level of service constitute an APFO. Approval or funding for new development proposals should be denied if they exceed existing servicing capabilities or fail to provide necessary services. 
Although some of the most suitable blocks were excluded from the analysis because they were in established urbanized areas, they should be investigated for infill development. These blocks have many of the attributes used in this analysis that aid compact growth, and may have vacant parcels suitable for new housing development. These areas should also be considered for redevelopment. In fact, positive programs to encourage higher residential densities and infill and redevelopment are necessary to apply a compact growth strategy. They are used in Colorado, Missouri, and Florida, and generally aid low to moderate- income housing developments (Nelson and Duncan 1995).

\section{Contiguous Development}

The most suitable locations for future residential developments determined from this study fall within the municipal boundaries. To some extent, the land within these boundaries could be considered as urban service areas. However, developing of any of the most suitable locations requires additional planning. They should be developed in a contiguous manner and phased in according to their proximity to existing services. For instance, it may be inappropriate to develop a block on the urban fringe due to the costs of extending public services (roads, electricity, water and sewer lines) without first developing property closer to existing infrastructure. Phasing and timing of blocks applies to future land uses within urban service areas. Timing methods suggest the chronological coordination of actions with respect to each other, or with respect to triggering an event (Nelson and Duncan 1995). For example, when several blocks approach their development capacity, additional services may have to be built on adjacent blocks so new development can utilize adequate public services. 
The Ministry of Housing, Palestinian Housing Council, MOPIC, and the Village Council should coordinate their activities so parcels are developed at the appropriate time with adequate public services (water, sewer, transportation). These agencies should also know the housing needs of residents, available land for development, and funding sources for infrastructure.

\section{Parcellation}

Another goal, parcellation, is achieved by grouping enough small parcels together to allow for a block's development. Since some parcels are divided into many long thin plots, as mentioned in Chapter Two, it would be difficult to build on many tracts of land owned by different individuals. Several tools are available to administer a parcellation process which would eventually facilitate the orderly development and servicing of fringe urban land. One method is called land pooling (Devas and Rakodi 1993). This may be undertaken by either a government agency, such as the Ministry of Local Government, or as a voluntary arrangement between land owners. Land pooling is increasingly being adopted in a number of Asian countries including Indonesia, South Korea, Japan, and India. Features of land pooling include an agreement between all land owners to have their land pooled and redistributed proportionally to best accommodate a housing development, measurement and layout of all plots, and surrendering of some plots to aid financing of an agreed level of infrastructure services (Devas and Rakodi 1993).

Another method to aid parcellation is to streamline the land and housing development process. Regulations that restrict development can reduce supply and thereby increase 
land prices (IBRD 1993). Parcels that are held vacant due to outdated laws and old zoning requirements may prevent contiguous development or restrict access to adjacent parcels. Therefore, regulations should be changed to open land to development that is more suited to housing than other land uses. Furthermore, reducing restrictions of land within the urban service area would make land more attractive to developers and speculators than land outside the urban service area. Local governments, including the Ministry of Local Governments and the Municipal Council, would have to change specific land use regulations.

\section{Comprehensive Plan}

The use of one tool alone will not result in compact growth, parcellation, or contiguous development within Gaza Strip. It will take the combination of several methods as described above to effectively administer an urban growth management strategy.

A comprehensive plan would ultimately represent the collection of all above methods and tools along with the goals of the communities. However, it would take several years before a plan could come to fruition, and this may be too late to manage lands presently under severe development pressure on the Strip.

\section{CONSTRAINTS}

There are several constraints which may prevent or limit land from being developed under a compact growth strategy. These constraints pertain to political, agricultural, and social issues. 


\section{Political Issues}

Several political barriers may restrict development of new residential areas. With a new government in control, there will most likely be internal power struggles and differences among decision makers. Brynen (1996b) reported that the emerging authority faced serious problems of institutionalization, and that appointments to administrative and technical units were driven by political favoritism and nepotism. There remain other political barriers with refugees and border closures as well.

Housing for refugees remains a chronic political problem. Most refugees have refused to move into new housing units because they had to meet three political criteria upon acceptance for resettlement from their camps during Israeli occupation. They had to (1) submit a written statement repudiating their status as refugees and dropping all claims as such; (2) start construction of a new housing unit within six months or lose entitlement to a new plot of land, as well as to their original camp shelter; and (3) demolish their camp shelters (Roy 1995). In light of these constraints, less than 10 percent of the refugee population moved into new units by 1989. This situation may only intensify Gaza's housing problem since the political status of the refugees remains unresolved.

Another constraint is with Israel's intermittent border closures which prevent entry of Palestinian workers into Israel. This restriction has occurred over the past few years and is associated with the degree of tension between the Israeli and Palestinian governments. These closures seriously undermine the economy of Gaza Strip and usually slow or stop 
development projects. These actions also reduce income levels and decrease the number of people that can afford new homes.

One underlying source of support for most development in Palestine has been from international economic aid and investment. In fact, more than three dozen donor countries pledged $\$ 2.5$ billion over a five year period (1994 - 1999) to foster Palestinian economic and social development in the West Bank and Gaza Strip (Brynen 1996a). Without this aid, the Palestinian Authority would not be able to administer many of its programs or complete projects. Donor disbursement was slow to be administered in 1994, but accelerated in 1996. It is important to note, however, that the long-term goals of donors, shaped by bureaucratic processes, the Palestinian Authority, and local conditions, are not always translated into practical realities (Brynen 1996b). International aid is only part of an overall peace-building process; the rest must come from within.

Since the Palestinian government relies on large sums of international donor aid for infrastructure projects, a withdrawal of a country's contribution could reduce or restrict proposed projects (Brynen 1996b). New development areas require all supporting infrastructure such as roads, water, sewer, and electric lines, planning, and design and management costs. If some supporting projects are not funded, new residential homes will be useless. 
Another problem lies with the lack of adequate housing development policies and a fragmented governance framework for the Gaza Strip (MOPIC 1995b:9, IBRD 1993). Compliance and enforcement is minimal, since at least 90 percent of all building activity is illegal (MOPIC 1995b). Antiquated rules from previous administrations and illegal building practices pose an obstacle to proper planning and development. Housing policies are urgently needed in combination with other planning regulations to form a unified, well-functioning planning framework.

\section{Agricultural Issues}

There is literally no unused land in Gaza Strip; all land is in some way worked or developed for a particular purpose. This means that there will have to be compensation for a shift to another type of land use if the new development does not replace an existing housing location. Most of the land developed in the past 30 years was agricultural, and it appears that urban area expansion will cause the loss of much additional agricultural land in the future (MOPIC 1995b).

Other agricultural issues may arise due to the limitation or scarcity of productive lands within the Strip. Should the government focus on becoming less dependent on food imports, the demand for local crops and land may conflict with the need to use land for development. Lands slated for development may also be incompatible with neighboring properties. For instance, if a new site is surrounded by areas of productive farmland, view sheds, light spaces, drainage patterns, and runoff may impact the agriculture lands. 
MOPIC is undecided on whether or not to boost the local economy by creating more manufacturing and/ or light-industrial jobs. An improved economy would allow residents to afford more imported goods, and hence become less reliant on the local production of crops. One example has occurred over the past several years where farmers have leaned toward intensive farming instead of extensive farming (e.g., tomatoes instead of oranges). Although this action may not necessarily reduce the need to import more agricultural products, it may support the decision to use agricultural land for development.

\section{Social Issues}

Population data are essential to know who needs housing and where the people currently live. Presently, planning agencies (UNRWA, MOPIC, et al. ) have relied on estimates and the number of registered residents. Thus, insufficient data may lead to an inaccurate projection of residential housing funding, and direct monies to wrong areas of development.

When MOPIC chooses a block for new housing development, some land owners and residents may oppose the decision. This may prevent the parcellation process, and not allow contiguous development. Community participation, necessary in planning for residential developments, has been poor since most decision-making has remained in the upper levels of the new government.

Another constraint to selecting a particular site may be availability of infrastructure support and public services if several sites require the same systems. In some instances, 
adjacent sites may utilize the same infrastructure depending on their proximity to major infrastructure and public services.

Finally, one major constraint to implementing a housing strategy is the ability of most Gazans to afford a new home. Recent construction with units built speculatively have priced most residents out of the market. Several other housing projects for middle income families remain mostly empty since cost overruns and increased building code requirements resulted in higher than expected rental and purchase amounts. 


\section{Chapter VI. Conclusions}

In this study, new locations for residential development in Gaza Strip were identified. An implementation program containing various planning methods to develop the most suitable locations was also presented. This final chapter reviews the results of the study, identifies limitations, and lists areas for further development.

\section{RESULTS OF MOST SUITABLE LOCATIONS}

\section{Locations}

This study identified 19 different suitable one-kilometer blocks of land for new housing developments. All of them have similar attributes necessary to provide needs for individuals who will be living in those areas and to create an efficient use and pattern of land. They concentrate around already established urban areas and prevent expensive extension of city services in a territory that is currently under high population growth and development pressure.

Coincidentally, 19 blocks of land will be needed over the next 15 years to meet the estimated population growth of 560,000 . These areas could accommodate high-density residential neighborhoods that provide school, religious, and recreational activities. Although the proposed density may seem high (17 du/ acre), urbanized areas within Gaza range from 8 to $24 \mathrm{du} /$ acre and up to $36 \mathrm{du} /$ acre in the refugee camps. 
The distribution of the most suitable blocks for residential development is revealing. About two-thirds of the blocks (11) were distributed around the urbanized area of Khan Younis (see FIGURE 10). This reflects two development concerns: 1) they are away from most environmental areas of concern and near urban services, and 2) they would result in compact growth and with contiguous development through proper implementation.

Several blocks were located around the urbanized fringes of Gaza City, and were mostly on the southern side. As expected, these areas respond to the same development concerns mentioned for blocks around Khan Younis. An important environmental concern is the water catchment (recharge) area located on the northern side of Gaza City, where there is one block. Since potable water is at critically low levels, development of these areas should proceed with caution.

A few blocks were identified in the smaller communities of Rafah and Dier Balah. Development of these areas would help accommodate residents that want to maintain ties to their communities. It would also reduce development pressure from the neighboring villages that utilize the same public services. Furthermore, there are no apparent areas of environmental concern that would be impacted from new residential neighborhoods.

\section{Implementation}

This study proposes an implementation plan that determines how and when these blocks should be developed. Several main goals need to be established by all agencies involved 
with housing and land use planning in the Strip. These goals of achieving compact growth, maintaining contiguous development, and group plots through parcellation will help foster appropriate uses of land in the Strip. Furthermore, proper zoning regulations should implemented as a basis for all goals.

These goals represent a growth management strategy which should be implemented in a coordinated manner. However, they do not constitute a comprehensive plan which generally takes many years of planning and community involvement. This implementation plan should impact decisions in light of inadequate information necessary for a detailed comprehensive plan and the urgency of housing needs throughout the Strip both now and in the future.

Furthermore, the implementation process recommends several planning methods and agencies to achieve these main goals. Some methods require regulatory changes (streamline permit process, zoning ordinances, and restrictive development), some are based on growth over time (infill development, urban service areas, and phasing), and others are procedural (land pooling and APFOs). The regulatory methods may be the most difficult to implement since there are probably similar regulations that have been used for many years. For instance, the city of Khan Younis is still using the Master Plan from the 1940s. Otherwise, these methods should adequately support the main implementation goals. 


\section{LIMITATIONS OF THE STUDY}

In a study of an area that has received little, if any, planning attention, there is some information that was either not available, or was related to the Palestinian Authority's and MOPIC's internal planning options. In the United States, we generally have access many studies and reports that relate to the topic at hand. With this study, there were very few reports available for comparison or insight in to the conditions and problems in Gaza Strip.

\section{Data Collection and Limitations}

One major difficulty with this investigation of housing in Gaza is the lack of material in general, and the reliability and adequacy of this material. First, much of the demographic data are either not available or not collected at a previous time. During Israeli occupation, military leaders based their needs on security, and collected information to maintain security, not necessarily for improvement of the Palestinians' social and environmental condition. Secondly, it was difficult to locate and obtain records and information from the State of Israel, not due to lack of cooperation, but due to the distance and concern about security issues. Thirdly, since the Palestinian Authority has maintained full civilian control of Gaza Strip for only three years, there has been little time to organize and collect demographic data considering the deplorable and crowded conditions in the Strip.

Another limitation was the availability of photographic data from the Israeli government. The Israeli government gave MOPIC a 1: 10,000 scale color aerial photograph of the 
Gaza Strip. It was laid out on a fifteen-foot board, and provided a very detailed view of the Strip. However, the settlement areas were not shown, and were patched over with photographs of nearby dunes. Apparently, the Israeli government did not want the Palestinians to know about land uses within the settlement areas. To put this in perspective, it would be similar to looking at an aerial map of South Kingstown, Rhode Island with all of the University or Rhode Island campus and Kingston Village replaced with a picture of trees. The topographic map of Gaza Strip, however, had some roads and built area that represented the settlements, and this provided some indication of this are land use. In this study, I compared topographic maps and aerial photographs as a check on land uses in the Strip. However, I could not perform this check without the aerial photograph of the settlement areas.

\section{Comments on Methodology and Analysis}

It is very important to address the use of agricultural lands and those affected or possibly displaced by new development on a site-specific basis, since there is a limited amount of productive land. These new areas may be incompatible with existing developments. MOPIC and other ministries should carefully monitor any plans to remove it from production.

Furthermore, density and community service needs for a particular population are not determined with this analysis. Community service standards provide the necessary information for school, business, and recreation, religious, municipal, and other community services and infrastructure needs, and are currently being developed in the 
Ministry (MOPIC 1996a). Such information could supplement the results of the suitability analysis.

This analysis does account for the importance of agricultural land in Gaza's economy. Other economic models may apply relative monetary contributions of particular agricultural areas. However, this analysis does not incorporate market values.

\section{Comments on Implementation}

Increasing the supply of homes may not necessarily alleviate Gaza's housing crisis. As mentioned earlier, many of the refugees living in camps, who comprise about one-third of the population, have refused to move into new locations and give up their refugee status without compensation for property lost in the 1948 war. Thus, demand for housing may actually be very small if one considers that two-thirds of the expected population will not desire a home.

\section{AREAS FOR FUTURE STUDY}

This study represents one component of a regional plan for Gaza Strip. Since few studies have been conducted in the Strip, there are many opportunities for future investigations. Additional studies would include the commercial, transportation, open space, and agriculture plans. Sectorial plans for the coastal zone, industrial parks, tourism, and archaeological areas are necessary as well. 
In reference to the methodology and analysis of this study, they could be applied to other areas that lack GIS information. This methodology could also be tested and refined using a more complete set of data. It could include more attributes, such as proximity to specific environmental features, and weight the attributes as well. This would give a more complete picture of land use activities, and allow for addition comparisons of locations using different weighting schemes.

New residential developments in Gaza Strip requires special attention since it will impact the lives of many Palestinians. One must not forget that the condition of a family's home is a reflection of their well being and of the community, and location of that home is part of it. This study represents an effort to help build new communities for Palestinians now and in the future. 


\section{APPENDIX 1. INTERIM AGREEMENT}

Selected paragraphs from the Israeli-Palestinian Interim Agreement

Annex I, Article VI. "Security Arrangements in the Gaza Strip [FIGURE 5]

1. The Delimiting Line

a. ...the line delimiting the northern edge of the Gaza Strip follows the fence on the ground, as delineated on attached map No. 2 by an unbroken green line...

b. ...the security fence between Gaza Strip and Israel shall remain in place, and that the line demarcated by the fence shall be authoritative only for the purpose of the Agreement.

2. Security Perimeter

a. There will be security perimeter along the Delimiting Line inside the Gaza Strip as delineated on map No. 2 by a broken green line...

c. The Palestinian Police will enforce special security measures aimed at preventing infiltrations across the Delimiting Line or the introduction into the Security Perimeter of and arms, ammunition or related equipment...

3. The Israeli Settlements

a. ...the Gush Katie and Erez settlement areas, as well as the other settlements in the Gaza Strip.... will be under Israeli authority.

b. Palestinians will be free to move along the coast road and along the road from the Netzarim Junction to the seashore.

4. The Yellow Area

a. responsibility will be shared as follows: the Israeli authorities will have the overriding responsibility and powers for security, and the Council will have the responsibility and powers for civil affairs...

5. The Mawasi Area

b. Access of Palestinians to the Mawasi area, as delineated on attached map No.

2, will be by the following roads:

1. Rafah - Tel Sultan - Mawasi

2. Khan Yunis - El Bahr Village; and

3. Deir El Ballah - along the beach to the Mawasi.

6. The Egyptian Border

The Military Installation Area along the Egyptian Border in the Gaza Strip, as delineated on attached map No. 2 by a blue line, will be under Israeli authority.

The village of Dahaniya will remain part of the Military Installation Area...

7. Lateral Roads to the Settlements

d. overpasses will be constructed on intersections between the Lateral roads and the central North- South road (Road No. 4)."

\section{Article XII "Security Arrangements Concerning Planning, Building, and} Zoning

b. 1. General Provisions

c. These arrangements will be reviewed within a period of six months form the signing of this Agreement, and, thereafter, every six months, with a view to 
modifying them, with due consideration to Palestinian plans for establishing economic projects, and to the security concerns of both sides.

3. Provisions regarding the Gaza Strip

a. The existing buildings, installations and natural and artificial culture in the Gaza Strip within distance of 100 meters from the Delimiting Line, shall remain as they are at present.

b. Within the next 500 meters of the Security Perimeter, and within the Yellow Area, buildings or installations may be constructed, provided that:

(1) one building or installation may be constructed on each plot, the size of which shall not be less than 25 dunams [6.25 acres]; and

(2) such building or installation shall not exceed two floors, of a size not exceeding $\quad 180$ sq. meters per floor.

c. The council shall maintain the predominantly agricultural character of the remaining areas of the Security Perimeter.

d. Buildings or installations shall not be constructed on either side of the Lateral Roads up to a distance of 75 meters from the center of these Roads."

\section{Article XIV "Security along the Coastline to the Sea of Gaza}

4. Gaza Strip Port

a. Plans for establishment for a port in the Gaza Strip in accordance with the DOP, its location, and related matters of mutual interest and concern,... will be discussed and agreed upon between Israel and the Council taking into consideration the provisions of Article XXX (Passages) of the Agreement."

\section{Annex III, Article 27. Planning and Zoning}

3. a. "The Palestinian side shall ensure that no construction close to the Settlements and military locations will harm, damage, or adversely affect them or the infrastructure serving them.

b. Accordingly, when the Palestinian side considers that a proposed Planning Scheme pertains to construction which may fall within subparagraph a. above (in particular: waste disposal sites, electric power stations and projects regarding sewage, hazardous materials or which may have a polluting impact), it shall provide the CAC with a copy of such a Planning Scheme prior to its entry into force.

A sub committee established by the CAC shall, upon by request of the Israeli side, discuss such Planning Scheme. Pending the decision of the committee, planning procedures shall not be concluded and no building activity shall be carried out pursuant to the said Planning Scheme." 


\section{REFERENCES}

Amirahmadi, Hooshang and Salah S. El-Shakhs. 1993. Urban development in the Muslim world. eds. New Brunswick: Rutgers.

Brynen, Rex. 1996a. International aid to the West Bank and Gaza: A primer. Pp .46-53 in Journal of Palestinian Studies. XXXV,2 (winter).

Brynen, Rex. 1996b. Buying peace? A critical assessment of international aid to the West Bank and Gaza. Pp. 79-92 in Journal of Palestinian Studies. XXXV,2 (winter).

Burrough, Peter A. 1995. Opportunities and limitations of GIS-based modeling of solute transport at the regional scale. in Proceedings: Applications of GIS to the modeling of non-point source pollutants in the vadose zone. ASA-CSSA-SSSA Bouyoucos Conference, Mission Inn, Riverside, CA. May 1-3. USDA-ARS, Riverside, California.

Devas, Nick and Carole Rakodi. 1993. Managing fast growing cities: New approaches to urban planning. New York: John Wiley \& Sons.

Euroconsult/ Iwaco. 1994. Gaza environmental profile: Part 2 \& part 3. Arnhem/ Rotterdam: Netherlands.

Goadby, Fredric and Moses Doukhan. 1982. The land law of Palestine. in Journal of Palestinian Studies XI,2/42 (winter).

Granott, A. 1952. The land system in Palestine: History and structure. London: Eyre and Spottiswoode.

Gronning, Oystein. Senior Norwegian Advisor, Directorate for Urban and Rural Planning, Ministry of Planning and International Cooperation. 1996. Personal communication. July. Gaza, Palestine.

Heiberg, Marianne and Geir Ovensen. 1994. Palestinian society in Gaza, West Bank and Arab Jerusalem: A survey of living conditions. FAFO Report 151.

Hopkins, Lewis D. 1977. Methods for generating land suitability maps: A comparative evaluation. in Journal of American Institute of Planners 43,4 (October).

Huxley, Sir Julian, Dr. J. Bronowski, Sir Gerald Barry, and James Fisher. 1972. Growth of ideas: Knowledge, thought, imagination. New York: Doubleday V10. 
IBCRD. 1993. Developing the occupied territories: An investment in peace, Volume 5 infrastructure. International Bank for Reconstruction and Development: The World Bank: Washington.

JPS. 1996. The peace process. Special Document File. in Journal of Palestinian Studies XXV,2 (winter).

Kaiser, Edward J. and Shirley F. Weiss. 1970. Public policy and the residential development process. Journal of the American Institute of Planners 36:30-37.

Landis, John D. 1995. Imagining land use futures. in Journal of the American Planning Association 61:438-57.

McHarg, Ian L. 1992. Design with nature. New York: John Wiley \& Sons.

MFA. 1994. Israeli Ministry of Foreign Affairs. The Oslo II Agreement. Tel Aviv.

MFA. 1995. Israeli Ministry of Foreign Affairs, State of Israel. Israeli-Palestinian Interim Agreement on the West Bank and the Gaza Strip. Washington, D.C. September 28.

MOPIC. 1995a. Emergency resources protection plan. Palestinian Authority: Physical Planning and Institutional Building Project (July).

MOPIC. 1995b. Housing strategy. Palestinian Authority. (preliminary version, July).

MOPIC. 1996. Structural plan for Gaza City. Palestinian Authority: Physical Planning and Institutional Building Project (January), Draft.

MOPIC. 1996a. Urban development in the West Bank and Gaza, new housing for the camp population. May 13. Memo. Ministry of Planning and International Cooperation/Directorate for Urban and Rural Planning: Gaza.

MOPIC. 1996b. The Gaza Regional Plan. draft document. Ministry of Planning and International Cooperation/Directorate for Urban and Rural Planning: Gaza.

Nelson, Arthur C. and James B. Duncan. 1995. Growth management principles \& practices. Chicago: APA.

Orni, Efraim and Elisha Efrat. 1980. Geography of Israel. fourth ed. Jerusalem: Israel Universities Press.

Roy, Sara. 1995. The Gaza Strip: The political economy of de-development. Washington: IPS. 
UNRWA. 1996. UNRWA-Gaza fact sheet: Registered refugees in the Gaza Strip. unofficial document. Public Information Office/ UNRWA: Gaza. 